Review

\title{
Review on the latest developments in modified vanadium-titanium-based SCR catalysts
}

\author{
Chuanmin Chen *, Yue Cao, Songtao Liu, Jianmeng Chen, Wenbo Jia \\ School of Environmental Science \& Engineering, North China Electric Power University, Baoding 071003, Hebei, China
}

\section{A R T I C L E I N F O}

\section{Article history:}

Received 5 March 2018

Accepted 3 April 2018

Published 5 August 2018

\section{Keywords:}

Vanadium-titanium-based catalyst

Selective catalytic reduction

Low-temperature denitration

$\mathrm{Hg}^{0}$ oxidation

Slip ammonia

$\mathrm{SO}_{2}$ oxidation

\begin{abstract}
A B S T R A C T
Vanadium-titanium-based catalysts are the most widely used industrial materials for $\mathrm{NO}_{x}$ removal from coal-fired power plants. Owing to their relatively poor low-temperature deNO $\mathrm{N}_{x}$ activity, low thermal stability, insufficient $\mathrm{Hg}^{0}$ oxidation activity, $\mathrm{SO}_{2}$ oxidation, ammonia slip, and other disadvantages, modifications to traditional vanadium-titanium-based selective catalytic reduction (SCR) catalysts have been attempted by many researchers to promote their relevant performance. This article reviewed the research progress of modified vanadium-titanium-based SCR catalysts from seven aspects, namely, (1) improving low-temperature deNO $\mathrm{O}_{x}$ efficiency, (2) enhancing thermal stability, (3) improving $\mathrm{Hg}^{0}$ oxidation efficiency, (4) oxidizing slip ammonia, (5) reducing $\mathrm{SO}_{2}$ oxidation, (6) increasing alkali resistance, and (7) others. Their catalytic performance and the influence mechanisms have been discussed in detail. These catalysts were also divided into different categories according to their modified components such as noble metals (e.g., silver, ruthenium), transition metals (e.g., manganese, iron, copper, zirconium, etc.), rare earth metals (e.g., cerium, praseodymium), and other metal chlorides (e.g., calcium chloride, copper chloride) and non-metals (fluorine, sulfur, silicon, nitrogen, etc.). The advantages and disadvantages of these catalysts were summarized. Based on previous studies and the author's point of view, doping the appropriate modified components is beneficial to further improve the overall performance of vanadium-titanium-based SCR catalysts. This has enormous development potential and is a promising way to realize the control of multiple pollutants on the basis of the existing flue gas treatment system.
\end{abstract}

(C) 2018, Dalian Institute of Chemical Physics, Chinese Academy of Sciences. Published by Elsevier B.V. All rights reserved.

\section{Introduction}

Nitrogen oxide $\left(\mathrm{NO}_{x}\right)$, one of the main precursor substances of photochemical smog, the greenhouse effect, acid rain, ozone depletion, and $\mathrm{PM}_{2.5}$, is an atmospheric pollutant in coal-fired flue gas that causes great harm to the ecosystem and human life [1]. According to a recent survey, $\mathrm{NO}_{x}$ emissions in China increase annually. Thus, in 2010, the emission load was about twice that recorded in 2000 and is expected to reach 19.7 Mt by 2020 [2] . Additionally, coal-fired power plants are considered to be the largest source of $\mathrm{NO}_{x}$ emissions, discharging $\sim 46 \%$ of the total $\mathrm{NO}_{x}$ emissions [1]. Therefore, reduction of the $\mathrm{NO}_{x}$ generated by coal-fired power plants has become imperative in the environmental field.

The current $\mathrm{NO}_{x}$ control technologies can be classified into three categories: combustion, pre-combustion, and post-combustion $\mathrm{NO}_{x}$ control [3]. Pre-combustion control refers to the selection of low-nitrogen fuel to inhibit the formation of $\mathrm{NO}_{x}$ from the source. Owing to fuel limitations, this method is rarely used in industry. Combustion control, also

\footnotetext{
* Corresponding author. Tel: +86-312-7525510; E-mail: hdccm@126.com

This work was supported by the Science and Technology Plan Project of Hebei Province of China (16273703D) and the Fundamental Research Funds for the Central Universities (2015ZD24, 2017XS123).

DOI: 10.1016/S1872-2067(18)63090-6 | http://www.sciencedirect.com/science/journal/18722067 | Chin. J. Catal., Vol. 39, No. 8, August 2018
} 
known as low-nitrogen oxide combustion technology, is mainly employed to reduce $\mathrm{NO}_{x}$ emissions by changing the combustion conditions and improving the production technique. This method requires relatively low cost. However, its $\mathrm{NO}_{x}$ removal rate can only reach $15 \%-30 \%$, making it difficult to meet the current requirements for environmental protection [4]. Post combustion control is the use of flue gas denitrification technology. It refers to the installation of denitrification devices in the flue tail by which the $\mathrm{NO}_{x}$ in the flue gas is converted into harmless nitrogen and other substances through physical and chemical reactions. Owing to its good $\mathrm{NO}_{x}$ removal performance and simple operation, this technique has been extensively utilized in coal-fired power plants.

Flue gas deNO $\mathrm{N}_{x}$ technology can be divided into selective catalytic reduction (SCR), non-SCR (NSCR), selective non-catalytic reduction (SNCR), SNCR/SCR mixed technology, oxidation, solid adsorption, absorption, catalytic decomposition, electron beam irradiation, etc. $[5,6]$. Among them, SCR has become the most widely used $\mathrm{NO}_{x}$ emission control method for flue gas treatment in coal-fired power plants, globally. This can be attributed to its high $\mathrm{NO}_{x}$ conversion efficiency and relatively mature process [7]. Its reaction principle is to reduce $\mathrm{NO}_{x}$ (including $\mathrm{NO}$ and minor $\mathrm{NO}_{2}$ ) to $\mathrm{N}_{2}$ selectively by ammonia, urea, $\mathrm{H}_{2}, \mathrm{HC}$, or other reductants present on a particular catalyst [1,7-9]. This method has the advantages of no by-product formation, simple equipment structure, high $\operatorname{deNO}_{x}$ efficiency, reliable operation, convenient maintenance, and low one-time investment. Ammonia is the most commonly used reductant in the SCR unit of a coal-fired power plant. The main $\mathrm{NH}_{3}$-SCR reactions are as follows [10]:

$$
\begin{gathered}
4 \mathrm{NO}+4 \mathrm{NH}_{3}+\mathrm{O}_{2} \rightarrow 4 \mathrm{~N}_{2}+6 \mathrm{H}_{2} \mathrm{O} \\
2 \mathrm{NO}_{2}+4 \mathrm{NH}_{3}+\mathrm{O}_{2} \rightarrow 3 \mathrm{~N}_{2}+6 \mathrm{H}_{2} \mathrm{O} \\
6 \mathrm{NO}+4 \mathrm{NH}_{3} \rightarrow 5 \mathrm{~N}_{2}+6 \mathrm{H}_{2} \mathrm{O} \\
6 \mathrm{NO}_{2}+8 \mathrm{NH}_{3} \rightarrow 7 \mathrm{~N}_{2}+12 \mathrm{H}_{2} \mathrm{O}
\end{gathered}
$$

\section{Research progress in SCR catalysts}

\subsection{Overview of SCR catalysts}

As the core of the SCR technology, catalysts are used to reduce the activation energy and reaction temperature of $\mathrm{NO}_{x}$ decomposition, increase the $\mathrm{N}_{2}$ selectivity in $\mathrm{NO}_{x}$ reduction products, avoid the occurrence of side reactions, and thereby improve the reaction efficiency. The selection of catalysts is important. Specifically, the qualified SCR catalysts should possess the following characteristics:

(1) High deNO ${ }_{x}$ activity;

(2) Strong anti-poisoning ability;

(3) High mechanical strength;

(4) Suitable operating temperature range.

Many catalysts have been proven to be active for SCR reactions. The main active components are noble and transition metal oxides, while $\mathrm{TiO}_{2}, \mathrm{Al}_{2} \mathrm{O}_{3}, \mathrm{SiO}_{2}$, zeolite, and carbon are often used as carriers. These catalysts possess different deNO ${ }_{x}$ properties and advantages and disadvantages, which are summarized in Table 1.

\subsection{Commercial vanadium-titanium-based catalysts}

Among the numerous denitrification catalysts, $\mathrm{V}_{2} \mathrm{O}_{5}-\mathrm{WO}_{3}$ $\left(\mathrm{MoO}_{3}\right) / \mathrm{TiO}_{2}$ catalysts have been the most widely used SCR catalysts in coal-fired power plants for many years [11-13]. Their $\mathrm{NO}_{x}$ conversion rates are $>90 \%$, while $\mathrm{N}_{2}$ selectivity among the production processes is high when the temperature is $>300{ }^{\circ} \mathrm{C}$. $\mathrm{TiO}_{2}$ is employed as the carrier for these catalysts. It provides a large specific surface area and porosity, which are beneficial to the catalytic reaction and adsorption of the reactants. As the main active substance in the catalysts, $\mathrm{V}_{2} \mathrm{O}_{5}$ exhibits strong catalytic activity and stability. It has a remarkable catalytic effect on NO reduction and performs even better when supported on $\mathrm{TiO}_{2}$. However, the vanadium content in the catalyst is usually low $(0.8 \%-1.2 \%)$ because $\mathrm{SO}_{2}$ can be oxidized to undesirable $\mathrm{SO}_{3}$ by $\mathrm{V}_{2} \mathrm{O}_{5}$ [44]. Thus, $\mathrm{WO}_{3}$ or $\mathrm{MoO}_{3}$ is used as adjuvant. By interacting with anatase $\mathrm{TiO}_{2}, \mathrm{WO}_{3}$ shows high catalytic activity [45], increases the Lewis sites on the catalysts [46], inhibits $\mathrm{TiO}_{2}$ sintering [47], improves $\mathrm{SO}_{2}$ resistance [48], and extends the reaction temperature window [49].

\begin{tabular}{|c|c|c|c|c|c|}
\hline Catalyst type & Active component & Carrier & Advantages & Disadvantages & Ref. \\
\hline $\begin{array}{l}\text { Commercial vanadi- } \\
\text { um-titanium-based } \\
\text { catalyst }\end{array}$ & $\mathrm{V}_{2} \mathrm{O}_{5}$ & $\mathrm{TiO}_{2}$ & $\begin{array}{l}\text { High low-temperature SCR activity; } \\
\text { high } \mathrm{SO}_{2} \text { resistance }\end{array}$ & $\mathrm{SO}_{2}$ oxidation & $\begin{array}{c}\text { e.g. } \\
{[11-14]}\end{array}$ \\
\hline Noble metals & $\mathrm{Ag}, \mathrm{Sn}$, etc. & $\mathrm{TiO}_{2}, \mathrm{Al}_{2} \mathrm{O}_{3}$, etc. & $\begin{array}{l}\text { High low-temperature SCR activity; } \\
\text { high } \mathrm{SO}_{2} \text { and } \mathrm{H}_{2} \mathrm{O} \text { resistance }\end{array}$ & $\begin{array}{c}\text { Narrow temperature } \\
\text { window; } \mathrm{NH}_{3} \text { oxidation; } \\
\mathrm{N}_{2} \mathrm{O} \text { generation; high cost }\end{array}$ & $\begin{array}{c}\text { e.g. } \\
{[15-17]}\end{array}$ \\
\hline Metal oxides & $\begin{array}{c}\mathrm{V}_{2} \mathrm{O}_{5}, \mathrm{CeO}_{2}, \mathrm{MNO}_{x}, \mathrm{CuO}, \\
\mathrm{FeO}_{x}, \mathrm{CoO}_{x}, \mathrm{CrO}_{x} \text { and some } \\
\text { metal composite oxides }\end{array}$ & $\mathrm{TiO}_{2}, \mathrm{Al}_{2} \mathrm{O}_{3}$, etc. & $\begin{array}{l}\text { High SCR activity at } 300-400^{\circ} \mathrm{C} \text {; } \\
\text { good thermal stability; } \\
\text { high poisoning resistance }\end{array}$ & $\begin{array}{l}\text { Poor low-temperature } \\
\text { activity }\end{array}$ & $\begin{array}{c}\text { e.g. } \\
{[18-32]}\end{array}$ \\
\hline Zeolite & $\mathrm{Ce}, \mathrm{Mn}, \mathrm{Cu}, \mathrm{Fe}, \mathrm{Co}, \mathrm{Cr}$, etc. & Zeolite & Broad temperature window & $\begin{array}{l}\text { Poor hydrothermal } \\
\text { stability }\end{array}$ & $\begin{array}{c}\text { e.g. } \\
{[33-39]}\end{array}$ \\
\hline Carbon-based catalyst & $\mathrm{V}_{2} \mathrm{O}_{5}, \mathrm{CeO}_{2}, \mathrm{MNO}_{x}$, etc. & $\begin{array}{l}\text { Active carbon (AC), active } \\
\text { carbon fiber (ACF), } \\
\text { carbon nanotubes (CNTs) }\end{array}$ & $\begin{array}{c}\text { Easy to regenerate; } \\
\text { large specific surface area; } \\
\text { high chemical stability; } \\
\text { high low-temperature activity }\end{array}$ & $\begin{array}{l}\text { Frequent regeneration; } \\
\text { high energy consump- } \\
\text { tion; poor } \mathrm{SO}_{2} \text { resistance }\end{array}$ & $\begin{array}{c}\text { e.g. } \\
{[40-43]}\end{array}$ \\
\hline
\end{tabular}

The specific $\mathrm{NO}_{x}$ removal mechanism over vanadi-

Table 1

Summary of the major SCR catalysts. 
um-titanium-based SCR catalysts has been studied in recent years [50-55]. It is generally accepted that adsorption of the reducing agent $\left.\mathrm{NH}_{3}\right)$ on the catalyst surface is strong, while NO adsorption is negligible. Thus, the $\operatorname{deNO}_{x}$ process is considered as the reaction of gaseous $\mathrm{NO}$ and adsorbed $\mathrm{NH}_{3}$, which follows the Eley-Rideal mechanism. According to previous studies, both Brönsted and Lewis acid sites have been found on the surface of vanadium-titanium-based catalysts [56]. Most researchers consider that Brönsted acid sites play an important role in the deNO ${ }_{x}$ reaction. They believe that the $\mathrm{NH}_{3}$ adsorbed on the Brönsted acid sites would form $\mathrm{NH}_{4}{ }^{+}$ions that are then oxidized into $-\mathrm{NH}_{3}{ }^{+}$by $\mathrm{V}^{5+}=\mathrm{O}$, while $\mathrm{H}-\mathrm{O}-\mathrm{V}^{4+}$ is generated. Subsequently, $-\mathrm{NH}_{3}{ }^{+}$reacts with gaseous $\mathrm{NO}$ to produce $-\mathrm{NH}_{3}+\mathrm{NO}$ and decomposes to $\mathrm{N}_{2}$ and $\mathrm{H}_{2} \mathrm{O}$. Moreover, $\mathrm{H}-\mathrm{O}-\mathrm{V}^{4+}$ is reoxidized by $\mathrm{O}_{2}$ in the flue gas and thus, returns to its initial state (Fig. 1) [57]. However, a few people insist that $\mathrm{NH}_{3}$ is first adsorbed on the Lewis acid sites. Thus, $\mathrm{NH}_{2}$ is formed after activation and dehydrogenation of $\mathrm{NH}_{3}$ and reacts with gaseous NO to generate nitrosamines $\left(\mathrm{NH}_{2} \mathrm{NO}\right)$ as the intermediate [51]. Considering these two points of view, the SCR reaction would occur following the oxidative dehydrogenation of $\mathrm{NH}_{3}$, regardless of the adsorption sites of ammonia [58].

The vanadium-titanium-based SCR catalyst has been proven to oxidize elemental mercury $\left(\mathrm{Hg}^{0}\right)$ into oxidized mercury $\left(\mathrm{Hg}^{2+}\right)$ in flue gas [59-62]. However, its $\mathrm{Hg}^{0}$ oxidation efficiency is unsatisfactory under most conditions. Only in the presence of sufficient $\mathrm{HCl}$ and $\mathrm{O}_{2}$ can the oxidation rate reach $80 \%-90 \%$ [63]. The reaction is as follows:

$$
2 \mathrm{Hg}^{0}+4 \mathrm{HCl}+\mathrm{O}_{2} \rightarrow 2 \mathrm{HgCl}_{2}+2 \mathrm{H}_{2} \mathrm{O}
$$

Two possible mechanisms have been proposed for this reaction, namely, the Eley-Rideal and Langmuir-Hinshelwood mechanisms. The former considers that gaseous $\mathrm{Hg}^{0}$ reacts with $\mathrm{HCl}$, which adsorbs on the vanadium-titanium-based catalyst surface to form $\mathrm{HgCl}_{2}$ [64-68]. On the other hand, the latter considers that the reaction takes place between the adsorbed $\mathrm{Hg}^{0}$ and $\mathrm{HCl}[69,70]$. The vanadium oxides in the catalyst also play a major role in the reaction process [71], while tungsten and molybdenum can enhance the mercury oxidation performance [71,72]. Commercial SCR catalysts can oxidize $\mathrm{Hg}^{0}$ in the flue gas as $\mathrm{HCl}$ is added [66,73-75] and the generated $\mathrm{Hg}^{2+}$ would subsequently be removed by the desulfurization system. To date, this is the most economical and feasible method available to control the mercury discharged from

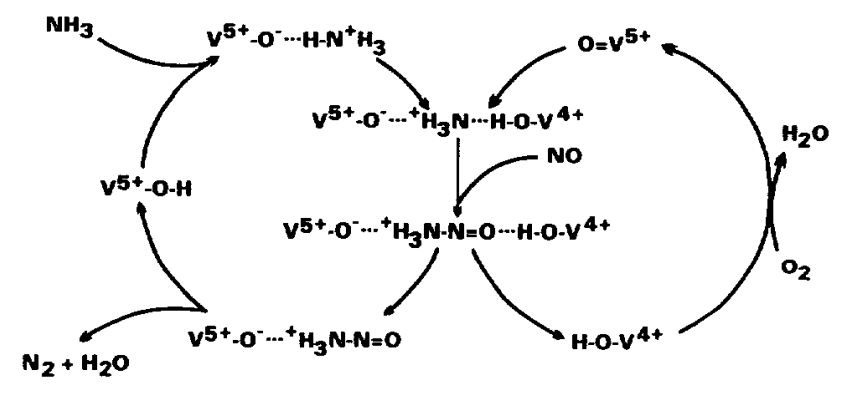

Acid Redox

Fig. 1. Brönsted acid mechanism of the SCR reaction [57] coal-fired power plants. However, inadequate $\mathrm{HCl}$ in the flue gas would significantly inhibit $\mathrm{Hg}^{0}$ oxidation [69]. Therefore, to achieve the synergistic removal of mercury when using low chlorine coal as a fuel, the stability and mercury oxidation effect of the SCR catalyst should to be further improved.

\subsection{Influencing factors of vanadium-titanium-based catalysts}

The operating conditions of the SCR system in coal-fired power plants are very complex. Many factors may affect the deNO $_{x}$ efficiency of the SCR catalysts, mainly in the following areas.

\subsubsection{Flue gas velocity}

An increase in flue gas velocity would accelerate the abrasion of the catalyst, as well as decrease the contact time of the catalyst and flue gas. This limits diffusion, adsorption, and the full reaction of the reactants, thereby reducing the $\mathrm{NO}_{x}$ removal rate. On the other hand, excessive contact time can lead to the oxidation of ammonia, which would also reduce the $\mathrm{NO}_{x}$ removal rate. The actual flue gas velocity of the SCR system in a coal-fired power plant is usually set to $3000-5000 \mathrm{~h}^{-1}$.

\subsection{2. $\mathrm{NH}_{3} / \mathrm{NO}_{x}$ ratio and degree of gas mixing}

Reactions (1)-(4) suggest that the $\mathrm{NO}_{x}$ removal efficiency improves as the $\mathrm{NH}_{3} / \mathrm{NO}_{x}$ ratio increases. However, the addition of an excessive amount of $\mathrm{NH}_{3}$ does not change the $\mathrm{NO}_{x}$ removal rate significantly. Instead, more $\mathrm{NH}_{3}$ is directly discharged into the atmosphere, causing secondary pollution. Thus, the $\mathrm{NH}_{3} / \mathrm{NO}_{x}$ ratio in the SCR system is usually maintained in the range of 0.8-1.2. Furthermore, the flue gas must be thoroughly mixed with the reductant before entering the SCR system to ensure that $\mathrm{NO}_{x}$ is adequately reduced by $\mathrm{NH}_{3}$. Limited reduction would also be detrimental to $\mathrm{NO}_{x}$ removal from the coal-fired power plant.

\subsubsection{Reaction temperature}

Based on previous studies, the operating temperature window of industrial vanadium-titanium-based catalysts is relatively narrow $\left(300-400{ }^{\circ} \mathrm{C}\right)$ [29,39]. In fact, increasing the temperature to its optimum value requires high energy consumption that cannot be reached in some power plants; thus, the actual deNO ${ }_{x}$ efficiency is rather low. When the operating temperature is $<320^{\circ} \mathrm{C}$, the activity and selectivity of the catalysts decrease and $\mathrm{SO}_{2}$ poisoning becomes more significant. In addition, high temperatures $\left(>400{ }^{\circ} \mathrm{C}\right)$ can lead to $\mathrm{TiO}_{2}$ sintering [76] and cause some side reactions, such as the production of $\mathrm{NO}$ and $\mathrm{N}_{2} \mathrm{O}$ from $\mathrm{NH}_{3}$ oxidation.

\subsubsection{Degradation of the catalytic performance}

Denitration efficiency decreases gradually with the aging of the catalysts. Thus, high-temperature sintering, catalyst pore plugging by particles, and the existence of $\mathrm{SO}_{2}$, water vapor, alkali metals, alkaline earth metals, lead, and arsenic [29,77-79] cause SCR catalyst deactivation during the SCR process. $\mathrm{SO}_{2}$ inhibition of the catalytic activity is the most prevalent. In the $\mathrm{NH}_{3}-\mathrm{SCR}$ process, the following $\mathrm{SO}_{2}$ poisoning 
mechanism is supposed: $\mathrm{SO}_{2}$ is oxidized on the catalyst surface. The generated $\mathrm{SO}_{3}$ reacts with the reductant to produce $\mathrm{NH}_{4} \mathrm{HSO}_{4}$ and $\left(\mathrm{NH}_{4}\right)_{2} \mathrm{SO}_{4}$. These two substances deposit in the catalysts pores, covering some active sites and leading to a sharp decline in the specific surface area of the catalysts [80]. Under normal SCR operating conditions, the $\mathrm{SO}_{2}$ conversion rate is in the range $1 \%-2 \%$ [81]. Studies have shown that the $\mathrm{V}=\mathrm{O}$ bond in the vanadium-titanium-based catalyst plays a key role in $\mathrm{SO}_{2}$ oxidation [82]. Therefore, the $\mathrm{V}_{2} \mathrm{O}_{5}$ content in the catalyst is usually set to be quite small to suppress $\mathrm{SO}_{3}$ generation. Water appears in the form of water vapor in the flue gas. The water vapor condensed on the catalyst surface not only exacerbates poisoning by the soluble salts of alkali metals, such as $\mathrm{K}$ and $\mathrm{Na}$, but also vaporizes and swells as the temperature increases. This impairs the fine structure and leads to cracking of the catalyst. Water vapor has been reported to compete with $\mathrm{NO}$ and $\mathrm{NH}_{3}$ for physical adsorption on the catalyst surface, thereby decreasing the deNO $\mathrm{O}_{x}$ activity [48]. The alkali metals in fly ash $(\mathrm{K}, \mathrm{Na})$ also degrade the catalytic performance since they become deposited in the active centers of the catalyst. Thus, long-term accumulation can block the pores on the catalyst and lead to catalyst poisoning [79].

\subsubsection{Ammonia slip}

Ammonia slip, the residual ammonia present in the downstream flue gas after the SCR system, is an important factor that influences the normal operation of the flue gas treatment system. A high gas velocity, high $\mathrm{NH}_{3} / \mathrm{NO}_{x}$ ratio, uneven $\mathrm{NH}_{3}$ and flue gas mixing, as well as a decrease in SCR catalytic activity all lead to the addition of slip ammonia [83]. This increase would severely affect the stability of the exhaust system. This occurs because slip ammonia further promotes the formation of the sulfate, leading to catalyst poisoning, a reduction in the heat transfer efficiency of the air preheater, corrosion, and blocking of the catalyst pores [84]. Moreover, studies have shown that $\mathrm{NH}_{3}$ competes for the active sites with $\mathrm{Hg}^{0}$. Hence, the $\mathrm{Hg}^{0}$ oxidation performance decreases with an increase in ammonia concentration [68]. Therefore, considering both the $\mathrm{Hg}^{0}$ conversion efficiency and the potential impact of ammonia emission, ammonia slippage from the SCR system should be minimized and is generally controlled to $\sim 3 \times 10^{-6}$. During actual operation, a reduction in the $\mathrm{NH}_{3} / \mathrm{NO}_{x}$ ratio has been considered as the main reducing method of ammonia slippage from coal-fired power plants. Nevertheless, as previously discussed, this method is not conducive to the SCR reaction.

\section{Recent advancements in modified vanadium-titanium-based SCR catalysts}

In view of the abovementioned influence factors, the vanadium-titanium-based catalysts in the $\mathrm{NH}_{3}-\mathrm{SCR}$ system have been modified in many studies to adapt to the various coal-fired power plant operating conditions to remove NO stably and efficiently. The main research directions are as follows: (1) broadening the reaction temperature of the catalysts, especially expansion to the low-temperature region, (2) improving the thermal stability, (3) enhancing the co-oxidation efficiency of elemental mercury, (4) controlling the slip ammonia, (5) reducing the rate of $\mathrm{SO}_{2}$ oxidation, (6) increasing the alkali resistance, and (7) others. In this paper, the research status of modified SCR catalysts in these aspects is analyzed and summarized.

\subsection{Improving low-temperature deNO $\mathrm{N}_{x}$ efficiency}

When the boiler starts and stops or is operated under low load, the flue gas temperature may be lower than the optimum operating temperature of a conventional SCR catalyst. Improving the low-temperature deNO ${ }_{x}$ efficiency of the SCR catalyst is beneficial to adapt to the actual operating conditions and cut down the energy consumption and deNO ${ }_{x}$ cost. Furthermore, a high temperature would promote $\mathrm{SO}_{2}$ oxidation, which is not expected to happen in an SCR system. Accordingly, many researchers have recently attempted to develop low-temperature $\left(<250{ }^{\circ} \mathrm{C}\right)$ SCR catalysts [84-87]. As they are placed before the desulfurization unit, these catalysts must withstand the high concentrations of $\mathrm{SO}_{2}$ present in the flue gas. This $\mathrm{SO}_{2}$ would lead to the destruction of the active components in the catalyst, while the surface-active sites would be covered by the generated metal and ammonium sulfates, which will completely inactivate the catalyst. Thus, poor sulfur resistance is considered to be the biggest bottleneck of most novel low-temperature SCR catalysts. Conversely, vanadium and other substances present in traditional SCR catalysts usually show excellent activity in high concentrations of $\mathrm{SO}_{2}$. Modification based on these components may be more feasible to develop ideal low-temperature $\mathrm{SCR}$ catalysts with good $\mathrm{SO}_{2}$ resistance.

Deng et al. [45] explored the influence of $\mathrm{WO}_{3}$ content on the low-temperature deNO $\mathrm{N}_{x}$ performance of SCR catalysts. According to their study, the $\mathrm{V}-\mathrm{W}$-Ti catalyst with increased $\mathrm{WO}_{3}$ content exhibited higher $\mathrm{NH}_{3}$-SCR activity at low temperatures compared to the vanadium-titanium catalysts. Particularly, the catalytic efficiency was $>80 \%$ at $180{ }^{\circ} \mathrm{C}$ when $7 \%$ tungsten was loaded. The highly dispersed $\mathrm{V}_{2} \mathrm{O}_{5}$ and $\mathrm{WO}_{3}$ on the catalyst surface and the exposed acidic sites may be responsible for this increase.

Tables 2 and 3 show some modified vanadium-titanium-based SCR catalysts with deNO ${ }_{x}$ activity at low temperatures, including both metal and non-metal doping catalysts. The preparation method, modification effect, and anti-poisoning performance are summarized.

\subsubsection{Metal-modified catalysts}

Owing to the strong redox ability and oxygen storage capacity of $\mathrm{CeO}_{2}$, ceria-based catalysts have been attracting increasing attention worldwide [88-90]. Ce can significantly increase both the low-temperature deNO $\mathrm{N}_{x}$ efficiency and reaction rate of vanadium-titanium-based SCR catalysts when doped into the carrier [91] or loaded as an additive [87,92]. Current studies generally believe that $\mathrm{Ce}$ and $\mathrm{V}$ may work synergistically. $\mathrm{Ce}^{3+}$ species would cause charge imbalance, vacant sites, and unsaturated chemical bonds, which increase the amount of chemisorbed oxygen and NO oxidation. Rich surface acidity, strong redox properties, and active intermediate species are the main 
Table 2

Metal-modified vanadium-titanium-based SCR catalysts for improving low-temperature deNO $\mathrm{O}_{x}$ activity.

\begin{tabular}{|c|c|c|c|c|c|c|c|c|}
\hline $\begin{array}{l}\text { Modified } \\
\text { component }\end{array}$ & Catalyst & Preparation method & $\begin{array}{c}T \\
\left({ }^{\circ} \mathrm{C}\right)\end{array}$ & $\begin{array}{l}\mathrm{DeNO}_{x} \\
\text { efficiency } \\
(\%)\end{array}$ & $\begin{array}{c}\mathrm{N}_{2} \\
\text { selectivity } \\
(\%)\end{array}$ & $\begin{array}{c}\text { Active } \\
\text { temperature } \\
\text { window }\left({ }^{\circ} \mathrm{C}\right)\end{array}$ & $\begin{array}{l}\text { Anti-poisoning } \\
\text { performance }\end{array}$ & Ref. \\
\hline $\mathrm{Ce}$ & $\begin{array}{c}1 \mathrm{wt} \%_{\mathrm{V}_{2} \mathrm{O}_{5}-10 \mathrm{wt} \%} \mathrm{WO}_{3} / \mathrm{CeO}_{2}-\mathrm{TiO} O_{2} \\
\text { (molar ratio of } \mathrm{Ce} / \mathrm{Ti}=1: 10 \text { ) }\end{array}$ & $\begin{array}{l}\text { Incipient wetness } \\
\text { impregnation }\end{array}$ & 325 & 100 & - & $250-475$ & Good $\mathrm{SO}_{2}$ resistance & [91] \\
\hline $\mathrm{Ce}$ & $\begin{array}{c}0.1 \mathrm{wt} \% \mathrm{~V}_{2} \mathrm{O}_{5}-6 \mathrm{wt} \% \mathrm{wO}_{3^{-}} \\
10 \mathrm{wt} \% \mathrm{Ce} / \mathrm{TiO}_{2}\end{array}$ & Wet impregnation & 200 & 90 & $>95$ & $200-475$ & $\begin{array}{l}\text { Good } \mathrm{SO}_{2} \text { and } \mathrm{H}_{2} \mathrm{O} \\
\text { resistances over } \\
200^{\circ} \mathrm{C}\end{array}$ & {$[87]$} \\
\hline $\begin{array}{l}\text { Promoters } \\
(\mathrm{W} / \mathrm{Ce})\end{array}$ & $\begin{array}{l}\text { Promoter } / \mathrm{V} / \mathrm{TiO}_{2} ; \\
\mathrm{V} / \text { promoter } / \mathrm{TiO}_{2} ; \\
\text { promoter-V/TiO }\end{array}$ & $\begin{array}{l}\text { Step-by-step impregnation } \\
\text { and co-impregnation }\end{array}$ & 300 & $>90$ & $>79$ & $225-375$ & - & [92] \\
\hline $\mathrm{Zr}, \mathrm{Ce}$ & $\begin{array}{c}\mathrm{CeO}_{2}-3 \mathrm{wt} \% \mathrm{~V}_{2} \mathrm{O}_{5} / \mathrm{TiO}_{2}-\mathrm{ZrO}_{2} \\
\text { (molar ratio of } \mathrm{Zr} / \mathrm{Ti} \text { and } \\
\mathrm{Ce} / \mathrm{Ti}-\mathrm{Zr}=1: 1,0.2 \\
\text { respectively) }\end{array}$ & $\begin{array}{l}\text { Co-precipitation and wet } \\
\text { impregnation }\end{array}$ & $\begin{array}{c}200 \\
/ 210-50\end{array}$ & $90 / 100$ & - & $150-475$ & - & [95] \\
\hline $\mathrm{Zr}, \mathrm{Ce}$ & $\begin{array}{c}1 \mathrm{wt} \% \mathrm{~V}_{2} \mathrm{O}_{5}-\mathrm{CeO}_{2} / \mathrm{TiO}_{2}-\mathrm{ZrO}_{2} \\
\text { (molar ratio of } \mathrm{Zr} / \mathrm{Ti}=1: 1 \\
\mathrm{Ce} / \mathrm{Ti}=0.2)\end{array}$ & $\begin{array}{l}\text { Co-precipitation and } \\
\text { step-by-step impregnation }\end{array}$ & 250 & 92 & - & $225-375$ & $\begin{array}{l}\text { Poor } \mathrm{H}_{2} \mathrm{O} \text { resistance } \\
\text { but good } \mathrm{SO}_{2} \text { re- } \\
\text { sistance. Inhibition } \\
\text { of } \mathrm{SO}_{2} \text { and } \mathrm{H}_{2} \mathrm{O} \text { is } \\
\text { reversible }\end{array}$ & [94] \\
\hline $\mathrm{Zr}, \mathrm{Ce}$ & $3.0 \mathrm{wt} \% \mathrm{Zr}-\mathrm{CeVO}_{4} / \mathrm{TiO}_{2}-\mathrm{NS}$ & Impregnation & $220-450$ & $>80$ & $>90$ & $220-450$ & $\begin{array}{l}\text { Good } \mathrm{SO}_{2} \text { and } \mathrm{H}_{2} \mathrm{O} \\
\text { resistances }\end{array}$ & {$[98]$} \\
\hline $\mathrm{Ce}, \mathrm{CNT}$ & $\begin{array}{c}\mathrm{V}_{2} \mathrm{O}_{5}-\mathrm{CeO}_{x} / \mathrm{TiO}_{2}-\mathrm{CNTs}(\text { molar } \\
\text { ratio of } \mathrm{Ce} / \mathrm{V}=9)\end{array}$ & Sol-gel & $\begin{array}{l}200 \\
/ 250\end{array}$ & $92 / 98$ & - & $175-300$ & $\begin{array}{l}\mathrm{SO}_{2} \text { poisoning effect } \\
\text { relied heavily on the } \\
\text { temperature and } \\
\text { gas velocity }\end{array}$ & [96] \\
\hline $\mathrm{Sb}$ & $2 \mathrm{wt} \% \mathrm{Sb} / 2 \mathrm{wt} \% \mathrm{~V}_{2} \mathrm{O}_{5} / \mathrm{TiO}_{2}$ & Impregnation & 300 & 100 & - & $225-400$ & $\begin{array}{c}\text { Good } \mathrm{SO}_{2} \text { resistance } \\
\text { in the presence of } \\
\mathrm{H}_{2} \mathrm{O}\end{array}$ & [106] \\
\hline $\mathrm{Sb}, \mathrm{Ce}$ & $\begin{array}{c}2 \mathrm{wt} \% \mathrm{Sb}-2 \mathrm{wt} \% \mathrm{~V}_{2} \mathrm{O}_{5}-10 \mathrm{wt} \% \\
\mathrm{Ce} / \mathrm{TiO}_{2}\end{array}$ & $\begin{array}{l}\text { Deposition-precipitation } \\
\text { and impregnation }\end{array}$ & 200 & $84 \%$ & $>95$ & $220-450$ & $\begin{array}{l}\text { Enhanced the } \mathrm{SO}_{2} \\
\text { resistance }\end{array}$ & [93] \\
\hline $\mathrm{Sb}, \mathrm{Ce}$ & $\begin{array}{c}\text { Sulfated } 2 \mathrm{wt} \% \mathrm{Sb} / 2 \mathrm{wt} \% \mathrm{~V} / \\
10 \mathrm{wt} \% \mathrm{Ce} / \mathrm{TiO}_{2} \\
\left(\mathrm{SO}_{2} \text { processing at }\right. \\
\left.300 / 400 / 500{ }^{\circ} \mathrm{C}\right)\end{array}$ & $\begin{array}{c}\text { Incipient wetness } \\
\text { co-impregnation and } \\
\text { deposition-precipitation }\end{array}$ & 220 & $>90$ & $>99$ & $200-300$ & - & [97] \\
\hline $\operatorname{Pr}$ & $\begin{array}{c}3 \text { wt } \% \mathrm{~V}_{2} \mathrm{O}_{5}-6 \text { wt } \% \mathrm{MoO}_{3} / \\
4 \text { wt } \% \mathrm{Pr}_{6} \mathrm{O}_{11}-\mathrm{TiO}_{2}\end{array}$ & Sol-gel and impregnation & 220 & 98 & $>95$ & $220-400$ & $\begin{array}{l}\text { Strong } \mathrm{SO}_{2} \text { and } \mathrm{H}_{2} \mathrm{O} \\
\text { resistances }\end{array}$ & [99] \\
\hline $\mathrm{Fe}$ & $\begin{array}{c}1 \mathrm{wt} \% \mathrm{~V}_{2} \mathrm{O}_{5}-10 \text { wt } \% \mathrm{WO}_{3} / \\
3 \mathrm{wt} \% \mathrm{Fe}_{2} \mathrm{O}_{3} / \mathrm{TiO}_{2} \text { nanoparti- } \\
\text { cles }\end{array}$ & Impregnation & 250 & 81.3 & - & $250-500$ & $\begin{array}{l}\text { Good } \mathrm{SO}_{2} \text { resistance. [ } \\
\text { Inhibition of } \mathrm{SO}_{2} \\
\text { was reversible }\end{array}$ & [100] \\
\hline $\mathrm{Fe}$ & $\begin{array}{l}\mathrm{VFe} / \mathrm{TiO}_{2} \text { nanoparticles (molar } \\
\text { ratio of } \mathrm{Fe} / \mathrm{Ti} \text { ratio }=0.03, \mathrm{~V} / \mathrm{Ti} \\
=0.17 \text { ) (using } 20 \mathrm{wt} \% \text { sepiolite } \\
\text { as binder) }\end{array}$ & Sol-gel & $<200$ & $<60$ & - & - & - & [103] \\
\hline $\mathrm{Cu}$ & $10 \mathrm{wt} \% \mathrm{CuO}-1 \mathrm{wt} \% \mathrm{~V}_{2} \mathrm{O}_{5} / \mathrm{TiO}_{2}$ & Wet impregnation & $\begin{array}{l}270 \\
/ 300\end{array}$ & $\begin{array}{c}70 \\
/ 100\end{array}$ & - & $230-320$ & $\begin{array}{l}\text { Good resistances to } \\
\mathrm{H}_{2} \mathrm{O} \text { and } \mathrm{SO}_{2} \text { at } \\
\text { activated } \\
\text { temperature }\end{array}$ & [101] \\
\hline $\mathrm{Cu}$ & $\begin{array}{l}\mathrm{Cu}-1 \mathrm{wt} \% \mathrm{~V}_{2} \mathrm{O}_{5} / \mathrm{WO}_{3}-\mathrm{TiO}_{2} \\
\text { (molar ratio of } \mathrm{Cu} / \mathrm{V}=1: 1 \text { ) }\end{array}$ & $\begin{array}{l}\text { Incipient wetness } \\
\text { impregnation }\end{array}$ & 250 & 84 & $\sim 95$ & $250-400$ & - & [102] \\
\hline
\end{tabular}

The deNO ${ }_{x}$ efficiency was $>80 \%$ in the active temperature window.

- No data available

reasons for the high deNO ${ }_{x}$ activity of Ce-doped SCR catalysts [87,91-97]. Furthermore, Zhang et al. [94,95] and Li et al. [96] respectively chose $\mathrm{TiO}_{2}-\mathrm{ZrO}_{2}$ and $\mathrm{TiO}_{2}$-carbon nanotubes (CNT) to replace raw $\mathrm{TiO}_{2}$ as the carrier for Ce-doping catalysts. In these cases, higher low-temperature deNO $\mathrm{N}_{x}$ activity was exhibited. However, the $\mathrm{V}_{2} \mathrm{O}_{5}-\mathrm{CeO}_{2} / \mathrm{TiO}_{2}-\mathrm{ZrO}_{2}$ catalysts possessed poor stability and $\mathrm{H}_{2} \mathrm{O}$ resistance despite the good resistance to $\mathrm{SO}_{2}$ poisoning. Additionally, the $\mathrm{SO}_{2}$ resistance of $\mathrm{V}_{2} \mathrm{O}_{5}-\mathrm{CeO}_{x} / \mathrm{TiO}_{2}$-CNTs varied greatly at different temperatures; thus, it was excellent at $250{ }^{\circ} \mathrm{C}$ but poor at $200^{\circ} \mathrm{C}$. In contrast, the $\mathrm{Zr}-\mathrm{CeVO}_{4} / \mathrm{TiO}_{2}$ catalyst prepared from $\mathrm{TiO}_{2}$ nanosheets $\left(\mathrm{TiO}_{2}-\mathrm{NS}\right)$ as the support showed the desired stability and 
Table 3

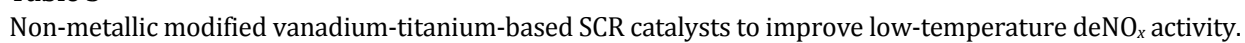

\begin{tabular}{|c|c|c|c|c|c|c|c|}
\hline Modified component & Catalyst & $\begin{array}{l}\text { Preparation } \\
\text { method }\end{array}$ & $T\left({ }^{\circ} \mathrm{C}\right)$ & $\begin{array}{c}\mathrm{DeNO}_{x} \\
\text { efficiency } \\
(\%) \\
\end{array}$ & $\begin{array}{l}\text { Active temperature } \\
\text { window }\left({ }^{\circ} \mathrm{C}\right)\end{array}$ & $\begin{array}{l}\text { Anti-poisoning } \\
\text { performance }\end{array}$ & Ref. \\
\hline \multirow[t]{3}{*}{$\bar{F}$} & \multirow{3}{*}{$\begin{array}{l}\mathrm{F}-1 \mathrm{wt} \% \mathrm{~V}_{2} \mathrm{O}_{5} / \mathrm{TiO}_{2}(\mathrm{molar} \\
\left.\text { ratio of } \mathrm{F} / \mathrm{Ti}=1.35 \times 10^{-2}\right)\end{array}$} & \multirow{3}{*}{$\begin{array}{c}\text { Sol-gel and } \\
\text { impregnation }\end{array}$} & 240 & 73 & - & \multirow{2}{*}{$\begin{array}{c}- \\
\text { Inhibitions of } \mathrm{H}_{2} \mathrm{O} \text { and } \mathrm{SO}_{2} \\
\text { were both reversible }\end{array}$} & {$[107]$} \\
\hline & & & 210 & 81.8 & - & & [110] \\
\hline & & & 240 & 98 & $200-250$ & $\begin{array}{l}\text { Significantly increased the } \\
\text { resistances to } \mathrm{SO}_{2} \text { and } \mathrm{H}_{2} \mathrm{O}\end{array}$ & [108] \\
\hline $\mathrm{N}$ & $\begin{array}{l}1 \mathrm{wt} \% \mathrm{~V}_{2} \mathrm{O}_{5} / \mathrm{N}-\mathrm{TiO}_{2}(\mathrm{molar} \\
\left.\text { ratio of } \mathrm{N} / \mathrm{Ti}=1.0 \times 10^{-2}\right)\end{array}$ & $\begin{array}{l}\text { Sol-gel and } \\
\text { impregnation }\end{array}$ & $240 / 270$ & $79.4 / 92$ & $240-270$ & $\begin{array}{c}\text { Excellent } \mathrm{SO}_{2} \text { and } \mathrm{H}_{2} \mathrm{O} \\
\text { resistances }\end{array}$ & [112] \\
\hline S & $\begin{array}{l}\mathrm{S}-1 \mathrm{wt} \% \mathrm{~V}_{2} \mathrm{O}_{5} / \mathrm{TiO}_{2}(\text { molar } \\
\text { ratio of } \mathrm{S} / \mathrm{Ti}=3 \times 10^{-2} \text { ) }\end{array}$ & $\begin{array}{c}\text { Sol-gel and } \\
\text { impregnation }\end{array}$ & 240 & 87 & $210-240$ & - & [113] \\
\hline BFS & $\begin{array}{c}2 \mathrm{wt} \% \mathrm{~V}_{2} \mathrm{O}_{5}-5 \mathrm{wt} \% \\
\mathrm{wO}_{3} / \mathrm{TiO}_{2}-\mathrm{SiO}_{2}(\mathrm{pH}=1)\end{array}$ & $\begin{array}{c}\text { Successive } \\
\text { impregnation }\end{array}$ & $200-400$ & 80 & - & $\begin{array}{l}\text { Excellent } \mathrm{SO}_{2} \text { and } \mathrm{H}_{2} \mathrm{O} \\
\text { resistances }\end{array}$ & [116] \\
\hline $\begin{array}{l}\mathrm{HPA} \\
\left(\mathrm{H}_{3} \mathrm{PW}_{12} \mathrm{O}_{40} / \mathrm{H}_{4} \mathrm{SiW}_{12}\right. \\
\left.\mathrm{O}_{40} / \mathrm{H}_{3} \mathrm{PMo}_{12} \mathrm{O}_{40}\right)\end{array}$ & $\begin{array}{c}15 \mathrm{wt} \% \mathrm{HPA}-5 \mathrm{wt} \% \\
\mathrm{~V}_{2} \mathrm{O}_{5} / \mathrm{TiO}_{2}\end{array}$ & Wet impregnation & 300 & 100 & $250-300$ & $\begin{array}{l}\text { Excellent resistance to } \\
\text { alkali }\end{array}$ & [117] \\
\hline
\end{tabular}

$\mathrm{H}_{2} \mathrm{O} / \mathrm{SO}_{2}$ durability in low-temperature $\mathrm{SCR}$ reactions [98]. This may occur because the formation of $\mathrm{NH}_{4} \mathrm{NO}_{3}$ and $\left(\mathrm{NH}_{4}\right)_{2} \mathrm{SO}_{4} / \mathrm{NH}_{4} \mathrm{HSO}_{4}$ was significantly inhibited and abundant active oxygen species and Brönsted acid sites were not covered in the presence of $\mathrm{H}_{2} \mathrm{O}$ and $\mathrm{SO}_{2}$. Similarly, $\mathrm{Pr}$, another rare earth metal, was also proven to be a good modifier [99]. When the doping content of $\mathrm{Pr}_{6} \mathrm{O}_{11}$ was 4 wt $\%, 98 \%$ of the $\mathrm{NO}_{x}$ was converted into $\mathrm{N}_{2}$ at $220{ }^{\circ} \mathrm{C}$ by $\mathrm{V}_{2} \mathrm{O}_{5}-\mathrm{MoO}_{3} / \mathrm{Pr}_{6} \mathrm{O}_{11}-\mathrm{TiO}_{2}$. Strong $\mathrm{SO}_{2}$ and $\mathrm{H}_{2} \mathrm{O}$ resistances were also exhibited.

Doping the common transition metals $\mathrm{Fe}$ [100] and $\mathrm{Cu}$ $[101,102]$, which would increase the amount of adsorbed oxygen and acid activity centers on the catalyst surface, often shows good low-temperature SCR efficiency and anti-poisoning performance. The transition metals and vanadium would form a redox cycle, thus improving the redox behavior of the catalyst. For example, the denitrification activity of the $\mathrm{V}_{2} \mathrm{O}_{5}-\mathrm{WO}_{3} / \mathrm{Fe}_{2} \mathrm{O}_{3} / \mathrm{TiO}_{2}$ nanoparticle catalyst was enhanced in the range $200-400{ }^{\circ} \mathrm{C}$ because of the promotional effect of $\mathrm{V}^{4++}$ $\mathrm{Fe}^{3+} \leftrightarrow \mathrm{V}^{5+}+\mathrm{Fe}^{2+}$ (Fig. 2) [100]. Moreover, the presence of $\mathrm{Cu}^{2+}$ $+\mathrm{V}^{4+} \leftrightarrow \mathrm{V}^{5+}+\mathrm{Cu}^{+}$(Fig. 3) promoted the Cu-doped $\mathrm{V}_{2} \mathrm{O}_{5} / \mathrm{WO}_{3}-\mathrm{TiO}_{2}$ catalyst to reach a deNO $\mathrm{N}_{x}$ efficiency of $84 \%$ and a $\mathrm{N}_{2}$ selectivity of $\sim 95 \%$ at $250{ }^{\circ} \mathrm{C}$ [102]. However, the $\mathrm{V}-\mathrm{Fe} / \mathrm{TiO}_{2}$ nanoparticle catalysts did not show good SCR activity at low temperatures in the presence of $20 \mathrm{vol} \% \mathrm{H}_{2} \mathrm{O}$. Their denitrification efficiencies were $<60 \%$ at $200{ }^{\circ} \mathrm{C}$ [103]. In addi-

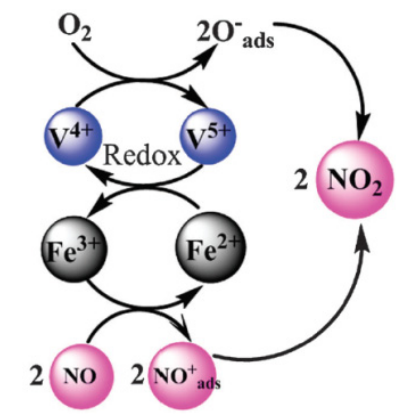

Fig. 2. Redox cycle of low-temperature deNO $\mathrm{N}_{x}$ on $\mathrm{V}_{2} \mathrm{O}_{5}-\mathrm{WO}_{3} / \mathrm{Fe}_{2} \mathrm{O}_{3} / \mathrm{TiO}_{2}$ nanoparticles [100]. tion, although loading on $\mathrm{TiO}_{2}$ can improve the SCR activity at low temperatures $\left(150-250{ }^{\circ} \mathrm{C}\right)[104,105]$, when added into $\mathrm{V}_{2} \mathrm{O}_{5} / \mathrm{TiO}_{2}$ as promoter, $\mathrm{MnO}_{x}$ had a negative effect on the SCR performance and slightly reduced $\mathrm{N}_{2} \mathrm{O}$ generation [92].

$\mathrm{Sb}$ is another promising modifier for commercial SCR catalysts. Compared to other modified SCR catalysts, the Sb-promoted SCR catalyst performed better during $\mathrm{NO}_{x}$ conversion at $150-400^{\circ} \mathrm{C}$, and was still effective at $230{ }^{\circ} \mathrm{C}$ after 90 $\mathrm{h}$ of $\mathrm{SO}_{2}$ deactivation (Fig. 4) [106]. Since more ammonium bisulfates were formed on $10 \mathrm{wt} \% \mathrm{~W}-\mathrm{V}_{2} \mathrm{O}_{5} / \mathrm{TiO}_{2}$ than on $2 \mathrm{wt} \%$ $\mathrm{Sb}-\mathrm{V}_{2} \mathrm{O}_{5} / \mathrm{TiO}_{2}$ [106], antimony may be a good substitute for tungsten to act as the auxiliary of the catalysts in low-temperature or low-sulfur content environments. In addition, Sb-Ce co-doping $[93,97]$ of the SCR catalysts also achieved a desirable $\mathrm{NO}_{x}$ reduction efficiency at low temperatures. Processing strong surface acidity and redox performance, $2 \mathrm{wt} \%$ $\mathrm{Sb}-2$ wt $\% \mathrm{~V}_{2} \mathrm{O}_{5}-10$ wt $\% \mathrm{Ce} / \mathrm{TiO}_{2}$ revealed the highest $\mathrm{NO}_{x}$ conversion rate of $84 \%$ and excellent $\mathrm{N}_{2}$ selectivity (>95\%) at 200 ${ }^{\circ} \mathrm{C}$ [93]. Moreover, after $\mathrm{SO}_{2}$ processing at high temperatures, excellent $\operatorname{deNO}_{x}$ activity was still revealed [97].This was attributed to the substantial $\mathrm{Ce}^{3+}$ ions and acid sites existing on its surface after the sulfidation treatment.

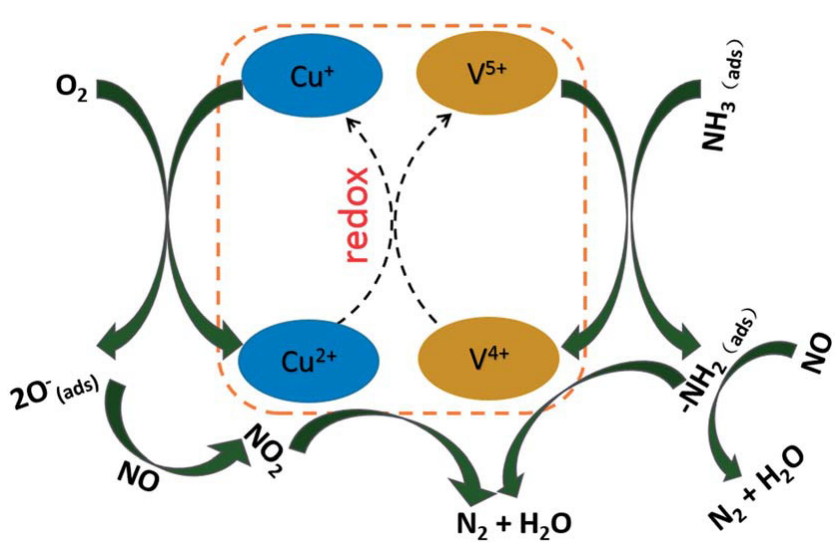

Fig. 3. Redox cycle of low-temperature $\operatorname{deNO}_{x}$ on $\mathrm{Cu}$-doped $\mathrm{V}_{2} \mathrm{O}_{5} / \mathrm{WO}_{3}-\mathrm{TiO}_{2}$ [102]. 


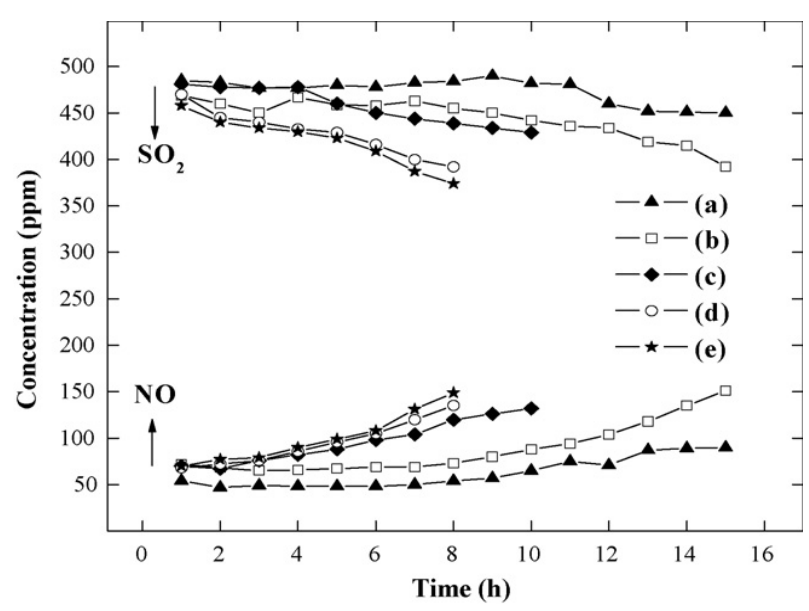

Fig. 4. $\mathrm{SO}_{2}$ deactivation study at $240{ }^{\circ} \mathrm{C}$ over $1 \% \mathrm{Sb} / \mathrm{V}_{2} \mathrm{O}_{5} / \mathrm{TiO}_{2}$ (a), $\mathrm{V}_{2} \mathrm{O}_{5} / \mathrm{TiO}_{2}$ (b), $1 \% \mathrm{Se} / \mathrm{V}_{2} \mathrm{O}_{5} / \mathrm{TiO}_{2}$ (c), $1 \% \mathrm{~S} / \mathrm{V}_{2} \mathrm{O}_{5} / \mathrm{TiO}_{2}$ (d) and $1 \%$ $\mathrm{Cu} / \mathrm{V}_{2} \mathrm{O}_{5} / \mathrm{TiO}_{2}$ (e). Reaction conditions: $800 \times 10^{-6} \mathrm{NO}_{x}, 800 \times 10^{-6} \mathrm{NH}_{3}$, 3 vol\% $\mathrm{O}_{2}, 6$ vol\% $\mathrm{H}_{2} \mathrm{O}, 500 \times 10^{-6} \mathrm{SO}_{2}, \mathrm{SV}=60000 \mathrm{~h}^{-1}$ ) [106]

The impregnation sequence of the promoters and $\mathrm{V}$ also influences the SCR activity and $\mathrm{N}_{2} \mathrm{O}$ selectivity [92]. According to research on Ce-, W-, Zr-, and Mn-SCR, the catalyst first added vanadium showed higher low-temperature deNO $\mathrm{N}_{x}$ activity. This superiority can be attributed to the formation of more $\mathrm{V}_{2} \mathrm{O}_{5}$ aggregates on the sample, which provides valuable information for the development of new SCR catalysts with excellent SCR performance.

\subsubsection{Non-metallic modified catalysts}

Common non-metals such as F [107-111], N [112], and S [113] can also improve the low temperature denitrification performance of vanadium-titanium-based catalysts (Table 3). They are usually doped into the $\mathrm{TiO}_{2}$ supporter by a sol-gel method to change the catalyst structure. Anatase $\mathrm{TiO}_{2}$ is more favorable to the SCR reaction [114]. Fortunately, these doped non-metals can inhibit the phase transition of $\mathrm{TiO}_{2}$ from anatase to rutile according to a series of characterization methods such as XPS, TPD, and EPR [107-113]. Moreover, the surface acidity, oxygen vacancies, and active sites can also be increased. The electron donors $\mathrm{NO}$ and $\mathrm{NH}_{3}$ reduce vanadium, and superoxide ions $\left(\mathrm{O}^{2-}\right)$ are then formed at the $\mathrm{V}$ sites. These superoxide ions promote the SCR reactions so that the SCR activity of the catalysts is directly proportional to the concentration of these superoxide ions. However, the coexistence of $\mathrm{H}_{2} \mathrm{O}$ and $\mathrm{SO}_{2}$ would synergistically inhibit the formation of $\mathrm{V}^{4+}$ and superoxide ions, thus restricting the SCR reaction [109].

These experimental results were also confirmed by theoretical calculations. Zhang et al. [115] investigated the cluster molecules of F-doped $\mathrm{V}_{2} \mathrm{O}_{5}-\mathrm{WO}_{3} / \mathrm{TiO}_{2}$ catalysts based on first-principle molecular dynamics and density functional theory. They found that atomic F replaced the bridge oxygen in $\mathrm{TiO}_{2}$ and formed an oxygen vacancy with high activity. Tungsten could interact with the oxygen vacancy, which can be promoted by vanadium, thus making the formation of superoxide ions advantageous.

Tran et al. [116] prepared $\mathrm{TiO}_{2}-\mathrm{SiO}_{2}$ supports using Ti-bearing blast furnace slags (BFS). On loading with $\mathrm{V}_{2} \mathrm{O}_{5}$ and
$\mathrm{WO}_{3}$, their low-temperature deNO $\mathrm{N}_{x}$ performance was significantly better than that of $\mathrm{V}_{2} \mathrm{O}_{5}-\mathrm{WO}_{3} / \mathrm{TiO}_{2}$. The presence of $\mathrm{SiO}_{2}$ and some impurities such as $\mathrm{CaO}, \mathrm{MgO}, \mathrm{Al}_{2} \mathrm{O}_{3}, \mathrm{Fe}_{2} \mathrm{O}_{3}$, and $\mathrm{SO}_{4}{ }^{2-}$ increased the surface area and acidity and promoted adsorption of the reactant.

Heteropoly acids (HPA), including $\mathrm{H}_{3} \mathrm{PW}_{12} \mathrm{O}_{40}, \mathrm{H}_{4} \mathrm{SiW}_{12} \mathrm{O}_{40}$, and $\mathrm{H}_{3} \mathrm{PMo}_{12} \mathrm{O}_{40}$ [117], were also used as a modifier to enhance the low-temperature $\mathrm{deNO}_{x}$ performance of commercial SCR catalysts. All the $15-\mathrm{wt} \% \mathrm{HPA}-\mathrm{V}_{2} \mathrm{O}_{5} / \mathrm{TiO}_{2}$ catalysts achieved $\sim 100 \%$ deNO $_{x}$ efficiency at $300{ }^{\circ} \mathrm{C}$ when the $\mathrm{V}_{2} \mathrm{O}_{5}$ content was 3-6 wt\%, which was better than that achieved by $10 \mathrm{wt} \%$ $\mathrm{WO}_{3}-\mathrm{V}_{2} \mathrm{O}_{5} / \mathrm{TiO}_{2}$. The addition of HPA could add acid sites and $\mathrm{V}^{4+}$ ions on the catalysts and promote the resistance to alkali poisoning. Further, neither $\mathrm{N}_{2} \mathrm{O}$ generation nor non-selective $\mathrm{NH}_{3}$ oxidation was increased.

\subsection{Enhancing thermal stability}

Following long-time running at high temperatures, conventional SCR catalysts would be sintered and $\mathrm{TiO}_{2}$ would convert from the anatase to the rutile phase. Therefore, the surface area and the catalytic activity of the catalysts can be greatly reduced [118]. To mitigate this problem, researchers have committed to improving the thermal stability of SCR catalysts.

Adding silicon to the carrier may be an available measure. The unfavorable phase transformation of $\mathrm{TiO}_{2}$ and the decrease in catalytic surface area can both be inhibited by $\mathrm{Si}$ doping. After hydrothermal treatment at $750{ }^{\circ} \mathrm{C}$ in 10 vol\% $\mathrm{H}_{2} \mathrm{O} /$ air for $24 \mathrm{~h}$, the stable structure of a $\mathrm{TiO}_{2}-\mathrm{WO}_{3}-\mathrm{SiO}_{2}$ supporter caused the vanadium oxide to form the most active polymer, other than $\mathrm{V}_{2} \mathrm{O}_{5}$ crystals, (Fig. 5) and maintain a good dispersion [119]. However, Casanova et al. [120] hold that Si doping alone could not efficiently promote the stability of vanadium-containing catalysts. They added rare earth and transition metals to the $\mathrm{V}_{2} \mathrm{O}_{5} / \mathrm{TiO}_{2}-\mathrm{WO}_{3}-\mathrm{SiO}_{2}$ catalyst and studied the resulting SCR performance [120-124]. Among these doping metals, $\mathrm{Fe}, \mathrm{Ce}, \mathrm{La}, \mathrm{Nd}$, and $\mathrm{Pr}$ were relatively sensitive to heat treatment, while $\mathrm{Tb}$, Er, Dy, Sm, and Gd showed outstanding anti-deactivation properties and high deNO $\mathrm{N}_{x}$ activity after thermal aging at $750^{\circ} \mathrm{C}$ in air $[120,122,123]$. The formed rare earth vanadates inhibited the rutilization of anatase $\mathrm{TiO}_{2}$. These components only partially decomposed at high temperatures and thus, improved the thermal resistance of the catalysts [123]. Similarly, the $\mathrm{Fe}_{x} \mathrm{Er}_{1-x} \mathrm{VO}_{4} / \mathrm{TiO}_{2}-\mathrm{WO}_{3}-\mathrm{SiO}_{2}$ catalyst possessed better thermal stability than the $\mathrm{FeVO}_{4} / \mathrm{TiO}_{2}-\mathrm{WO}_{3}-\mathrm{SiO}_{2}$

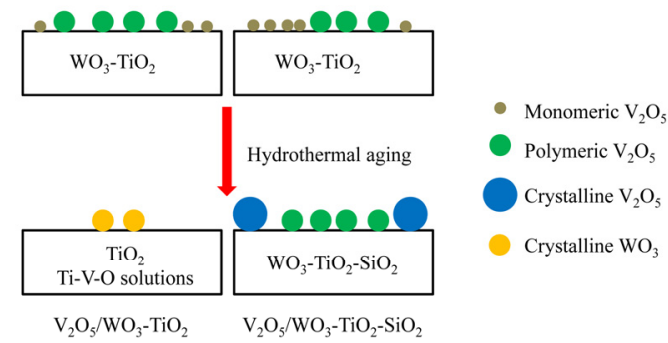

Fig. 5. Changes in $\mathrm{V}_{2} \mathrm{O}_{5} / \mathrm{WO}_{3}-\mathrm{TiO}_{2}$ and $\mathrm{V}_{2} \mathrm{O}_{5} / \mathrm{WO}_{3}-\mathrm{TiO}_{2}-\mathrm{SiO}_{2}$ catalysts after hydrothermal treatment [119]. 


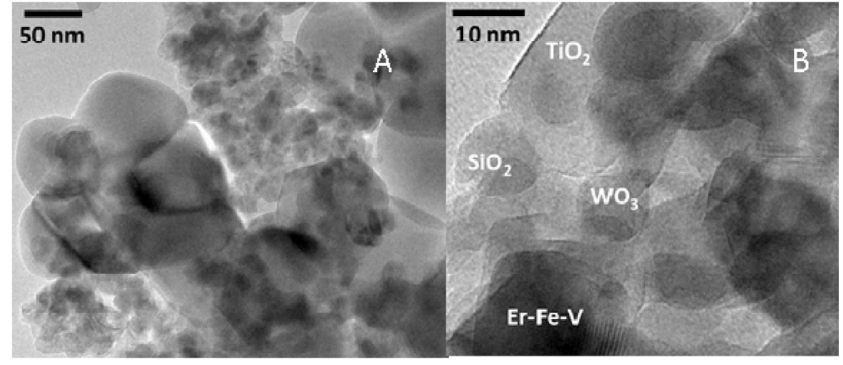

Fig. 6. TEM images (A, B) recorded over sample $\mathrm{Fe}_{0.5} \mathrm{Er}_{0.5} \mathrm{VO}_{4} / \mathrm{TiO}_{2}-\mathrm{WO}_{3}-\mathrm{SiO}_{2}$ catalyst aged at $750{ }^{\circ} \mathrm{C}[124]$.

catalyst due to the presence of erbium-iron vanadate after thermal aging at $750{ }^{\circ} \mathrm{C}$ (Fig. 6) [124].

Similarly, zirconium was used as a modifier to increase the thermal stability of the vanadium-containing catalysts by changing the vanadium speciation [125]. After aging treatment at $750{ }^{\circ} \mathrm{C}$ for $12 \mathrm{~h}$, the $10 \mathrm{wt} \% \mathrm{Zr}-1 \mathrm{wt} \% \mathrm{~V}_{2} \mathrm{O}_{5} / \mathrm{TiO}_{2}-\mathrm{WO}_{3}$ catalyst showed high SCR efficiency at $150-400^{\circ} \mathrm{C}$. However, the deNO$_{x}$ activity on the fresh catalysts was reduced by zirconium doping at temperatures $<400{ }^{\circ} \mathrm{C}$, which can be attributed to the decreased $\mathrm{V}^{5+}=0$ and Brönsted active sites.

The presence of tungsten and barium would also influence the thermal stability of the SCR catalysts [126]. After thermal aging at $600{ }^{\circ} \mathrm{C}$ for $6 \mathrm{~h}$, the deNO $\mathrm{N}_{x}$ efficiency of $6 \mathrm{wt} \% \mathrm{~W}-2 \mathrm{wt} \%$ $\mathrm{V}_{2} \mathrm{O}_{5} /$ sulfated $\mathrm{TiO}_{2}$ did not change significantly since $\mathrm{TiO}_{2}$ conversion was low. However, the $2 \mathrm{wt} \% \mathrm{Ba}-2 \mathrm{wt} \% \mathrm{~V}_{2} \mathrm{O}_{5} /$ sulfated $\mathrm{TiO}_{2}$ was dramatically deactivated due to the generation of $\mathrm{V}-\mathrm{O}-\mathrm{Ba}$, an inactive vanadium species for the SCR reaction.

$\mathrm{Yu}$ et al. [127] found that the deposited potassium could form $\mathrm{V}-\mathrm{O}-\mathrm{K}$ species, inhibited the aggregation of vanadium oxides, and thus, improved the thermal stability of the catalysts (Fig. 7). Compared to unmodified vanadium-titanium-based catalysts, this species could increase the deNO ${ }_{x}$ efficiency threefold after treatment at $800{ }^{\circ} \mathrm{C}$ for $4-5 \mathrm{~h}$.

These studies may help us find more detail on the sintering and rutilization processes of $\mathrm{TiO}_{2}$, and are conducive to improving the stability and denitrification activity of SCR catalysts to increase their service life.

\subsection{Improving the $\mathrm{Hg}^{0}$ oxidation efficiency}

Mercury is a volatile and poisonous trace element that ex-

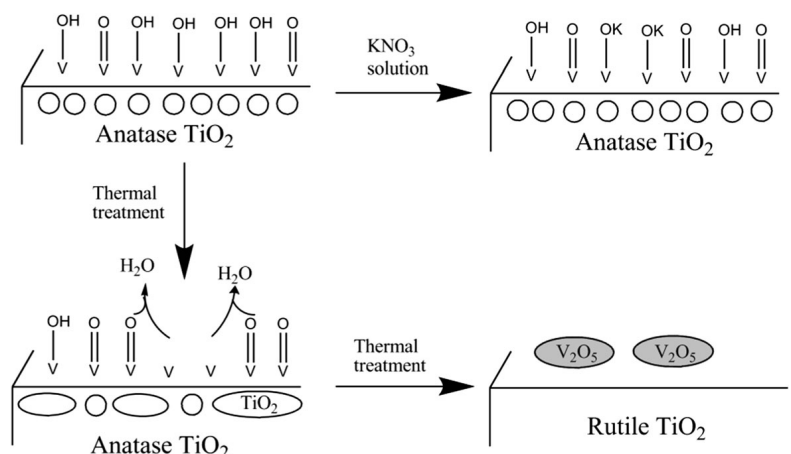

Fig. 7. Rutilization process of the SCR catalyst and formation of the K/SCR catalyst [127]. hibits migration, persistence, high biological enrichment, as well as nerve toxicity. It can easily cause environmental pollution and serious health hazards to human beings and thus, has been recognized as one of the persistent environmental pollutants to be preferentially controlled globally [128,129]. In 2013, the EPA updated the Mercury and Air Toxics Standard (MATS) requirements, in which the total mercury emissions from new units using low-rank raw coal as a fuel should be controlled to levels $<0.003 \mathrm{lb} /$ GWh [130].

Currently, coal combustion accounts for $\sim 45 \%$ of the anthropogenic mercury sources [131]. According to the literature, the mercury in coal-fired flue gas usually exists in three forms: elemental mercury $\left(\mathrm{Hg}^{0}\right)$, oxidized mercury $\left(\mathrm{Hg}^{2+}\right)$, and particulate mercury ( $\mathrm{Hgp}$ ) [132], of which $\mathrm{Hg}^{0}$ is the most difficult to handle because of its high volatility and low water solubility. Among the current $\mathrm{Hg}^{0}$ removal technologies from coal-fired flue gas, the use of catalysts to convert $\mathrm{Hg}^{0}$ to $\mathrm{Hg}^{2+}$, which can be removed by existing desulphurization equipment, is economical and practical. This technique has good future application prospects. In this method, the ratio of $\mathrm{Hg}^{2+}$ in the flue gas determines the mercury removal efficiency. Therefore, it is of great significance to improve the catalytic oxidation performance of $\mathrm{Hg}^{0}$.

Kamata et al. [67] investigated the $\mathrm{Hg}^{0}$ oxidation performance of metallic oxide-modified $\mathrm{TiO}_{2}$ catalysts. According to their study, the mercury oxidation efficiency is of the order of $\mathrm{MoO}_{3}>\mathrm{V}_{2} \mathrm{O}_{5}>\mathrm{CrO}_{3}>\mathrm{Mn}_{2} \mathrm{O}_{3}>\mathrm{Fe}_{2} \mathrm{O}_{3}>\mathrm{CuO}>\mathrm{NiO}$ in the absence of $\mathrm{NH}_{3}$. This indicates that $\mathrm{V}_{2} \mathrm{O}_{5}$, as the main active component in commercial SCR catalysts, is one of the most effective metal oxides for $\mathrm{Hg}^{0}$ catalytic oxidation. In fact, many mercury oxidation catalysts have been developed [133], such as $\mathrm{Au} / \mathrm{TiO}_{2}[134], \quad \mathrm{CuO} / \mathrm{TiO}_{2} \quad[135], \quad \mathrm{CeO}_{2} / \mathrm{TiO}_{2} \quad$ [136], $\mathrm{MNO}_{x}-\mathrm{CeO}_{2} / \mathrm{TiO}_{2} \quad[137,138], \quad \mathrm{CuO}-\mathrm{CeO}_{2} / \mathrm{TiO}_{2} \quad[139,140]$, $\mathrm{V}_{2} \mathrm{O}_{5} / \mathrm{ZrO}_{2}-\mathrm{CeO}_{2}$ [141], $\mathrm{MNO}_{x}-\mathrm{CeO}_{2}-\mathrm{ZrO}_{2}$ [142], Co-Ce- $\mathrm{ZrO}_{2}$ [143], $\mathrm{Mn} / \gamma-\mathrm{Al}_{2} \mathrm{O}_{3}$ [144], $\mathrm{CuCl}_{2} / \gamma-\mathrm{Al}_{2} \mathrm{O}_{3}$ [145], Nb-Co-Ce $/ \mathrm{Al}_{2} \mathrm{O}_{3}$ [146], Fe-Ti-Mn spinel [147], and Co-MF[148]. Although all these catalysts demonstrated a high mercury oxidation efficiency, their components are quite different from the traditional vanadium-titanium-based catalysts and thus, their application to $\operatorname{deNO}_{x}$ flue gas is uncertain. Moreover, the addition of these mercury oxidation catalysts may require transformation of the existing flue gas treatment equipment, which will result in a significant increase in cost. Therefore, adding other substances without altering the existing components of the SCR catalysts, to enhance the $\mathrm{Hg}^{0}$ oxidation performance while maintaining high deNO $\mathrm{N}_{x}$ efficiency, has aroused great concern.

According to previous studies, modification by transition metals (Fe [149] , Cu [150], Ag [151] , Ru [152,153] , Ce [154-156], etc.), metal chlorides ( $\mathrm{CaCl}_{2}$ [157], $\mathrm{CuCl}_{2}$ [158], etc.), and non-metallic species ( $\mathrm{Si}$ [159], etc.) can improve the elemental mercury oxidation properties of $\mathrm{V}_{2} \mathrm{O}_{5}-\mathrm{WO}_{3} / \mathrm{TiO}_{2}$ catalysts, which are summarized in Table 4 . The reaction conditions are also listed here since they may dramatically affect the mercury oxidation efficiency.

Huang et al. [149] investigated the influence of transition metal oxide doping on the mercury oxidation of traditional SCR catalysts. Fig. 8 reveals that in the presence of $8 \times 10^{-6} \mathrm{HCl}$, $\mathrm{ZnO}$, 
Table 4

Modified vanadium-titanium-based SCR catalysts for synergistic mercury oxidation.

\begin{tabular}{|c|c|c|c|c|c|c|c|}
\hline $\begin{array}{l}\text { Modified } \\
\text { compo- } \\
\text { nents }\end{array}$ & Catalyst & $\begin{array}{l}\text { Preparation } \\
\text { method }\end{array}$ & $\begin{array}{l}\mathrm{Hg}^{0} \text { oxidation } \\
\text { efficiency } \\
(\%)\end{array}$ & Reaction conditions & DeNO $_{x}$ activity & $\begin{array}{l}\text { Anti-poisoning } \\
\text { performance }\end{array}$ & Ref. \\
\hline $\mathrm{Fe}$ & $1 \mathrm{wt} \% \mathrm{Fe}_{2} \mathrm{O}_{3} / \mathrm{SCR}$ & Impregnation & $>90$ & $\begin{array}{c}120 \mu \mathrm{g} / \mathrm{m}^{3} \mathrm{Hg}^{0}, 8 \times 10^{-6} \mathrm{HCl}, \\
5 \% \mathrm{O}_{2}, \mathrm{~N}_{2} \text { as balance gas, } \\
\mathrm{GHSV}=7.2 \times 10^{5} \mathrm{~h}^{-1}, 350{ }^{\circ} \mathrm{C}\end{array}$ & - & $\begin{array}{l}\mathrm{SO}_{2} \text { slightly inhibited } \\
\mathrm{Hg}^{0} \text { oxidation }\end{array}$ & [149] \\
\hline $\mathrm{Cu}$ & $\begin{array}{c}3 \text { wt } \% \mathrm{CuO}-0.8 \text { wt } \% \\
\mathrm{~V}_{2} \mathrm{O}_{5}-\mathrm{WO}_{3} / \mathrm{TiO}_{2}\end{array}$ & $\begin{array}{c}\text { Improved } \\
\text { impregnation }\end{array}$ & 85.43 & $\begin{array}{c}7 \mu \mathrm{g} / \mathrm{m}^{3} \mathrm{Hg}^{0}, 5 \% \mathrm{O}_{2}, 12 \% \mathrm{CO}_{2}, \\
600 \times 10^{-6} \mathrm{SO}_{2}, 300 \times 10^{-6} \mathrm{NO}, 8 \% \\
\mathrm{H}_{2} \mathrm{O}, \mathrm{N}_{2} \text { as balance gas, } \\
\mathrm{GHSV}=1.2 \times 10^{5} \mathrm{~h}^{-1}, 350^{\circ} \mathrm{C}\end{array}$ & - & $\begin{array}{l}\mathrm{SO}_{2} \text { and } \mathrm{H}_{2} \mathrm{O} \text { slightly } \\
\text { inhibited } \mathrm{Hg}^{0} \text { oxidation }\end{array}$ & [150] \\
\hline $\mathrm{Ag}$ & $\begin{array}{c}\mathrm{Ag}-\mathrm{V}_{2} \mathrm{O}_{5}-\mathrm{TiO}_{2} \text {-polyvinyl } \\
\text { pyrrolidone (PVP) } \\
\text { (molar ratio of } \\
\mathrm{Ag} / \mathrm{Ti}=1, \mathrm{~V} / \mathrm{Ti}=1 \text { ) }\end{array}$ & Impregnation & $>90$ & $\begin{array}{c}\mathrm{Hg}^{0}, 5 \times 10^{-6} \mathrm{HCl}, 4 \% \mathrm{O}_{2}, \mathrm{~N}_{2} \text { as the } \\
\text { balance, } \mathrm{SV}=4.26 \times 10^{5} \mathrm{~h}^{-1}, 350 \\
{ }^{\circ} \mathrm{C}\end{array}$ & - & $\begin{array}{c}\text { Exhibited some } \mathrm{SO}_{2} \\
\text { resistance }\end{array}$ & [151] \\
\hline $\mathrm{Ru}$ & $\begin{array}{c}\mathrm{Ru} / \mathrm{SCR} \\
\text { (molar ratio of } \\
\mathrm{Ru} / \mathrm{Ti}=0.5 \text { ) }\end{array}$ & $\begin{array}{c}\text { Multi- } \\
\text { impregnation }\end{array}$ & $>90$ & $\begin{array}{c}50 \times 10^{-6} \mathrm{Hg}^{0}, 500 \times 10^{-6} \mathrm{SO}_{2} \\
300 \times 10^{-6} \mathrm{NO}, 4 \% \mathrm{H}_{2} \mathrm{O}, 5 \times 10^{-6} \\
\mathrm{HCl} \text {, and air as the balance, } \\
\mathrm{SV}=7.9 \times 10^{5} \mathrm{~h}^{-1}, 350^{\circ} \mathrm{C}\end{array}$ & $\begin{array}{c}\text { No obvious } \\
\text { negative effects }\end{array}$ & $\begin{array}{l}\text { Excellent } \mathrm{SO}_{2}, \mathrm{H}_{2} \mathrm{O} \text {, and } \\
\mathrm{NH}_{3} \text { resistances; no } \\
\text { significant negative } \\
\text { effects on } \mathrm{SO}_{2} \\
\text { transformation }\end{array}$ & {$[152]$} \\
\hline Mo, Ru & $\begin{array}{c}\text { Mo- } \mathrm{Ru} / \mathrm{SCR} \\
\text { (molar ratio of } \\
\mathrm{Ru} / \mathrm{Ti}=0.2 \% \text {, } \\
\mathrm{Mo} / \mathrm{Ti}=1 \% \text { ) }\end{array}$ & $\begin{array}{c}\text { Wet } \\
\text { impregnation }\end{array}$ & 86 & $\begin{array}{c}200 \mu \mathrm{g} / \mathrm{m}^{3} \mathrm{Hg}^{0}, 4 \% \mathrm{O}_{2}, 500 \times 10^{-6} \\
\mathrm{SO}_{2}, 50 \times 10^{-6} \mathrm{NH}_{3}, 100 \times 10^{-6} \mathrm{NO}, \\
4 \% \mathrm{H}_{2} \mathrm{O}, 5 \times 10^{-6} \mathrm{HCl}, \\
\text { and } \mathrm{N}_{2} \text { as the balance, } \\
\mathrm{SV}=5.9 \times 10^{5} \mathrm{~h}^{-1}, 350^{\circ} \mathrm{C}\end{array}$ & $\begin{array}{l}\text { Maintained high } \\
\text { deNO } \\
\text { and } \mathrm{N}_{2} \text { selficienctivity }\end{array}$ & $\begin{array}{l}\mathrm{SO}_{2} \text { and } \mathrm{NH}_{3} \\
\text { resistances were } \\
\text { increased }\end{array}$ & {$[153]$} \\
\hline $\mathrm{Si}$ & $\begin{array}{c}\mathrm{SiO}_{2}-6 \mathrm{wt} \% \mathrm{TiO}_{2}-5 \\
\text { wt } \% \mathrm{~V}_{2} \mathrm{O}_{5}\end{array}$ & Sol-gel & 99 & $\begin{array}{c}15-16.5 \mathrm{ppb} \mathrm{Hg}^{0}, 4 \% \mathrm{O}_{2}, 12 \% \\
\mathrm{CO}_{2}, 8 \% \mathrm{H}_{2} \mathrm{O}, 10 \times 10^{-6} \mathrm{HCl}, \\
400 \times 10^{-6} \mathrm{SO}_{2}, 300 \times 10^{-6} \mathrm{NO} \\
10 \times 10^{-6} \mathrm{NO}_{2}, \mathrm{~N}_{2} \text { as balance gas, } \\
\text { total flow rate }=1.5 \mathrm{LPM}\end{array}$ & - & $\begin{array}{c}\mathrm{H}_{2} \mathrm{O} \text { inhibited the } \mathrm{Hg}^{0} \\
\text { oxidation while } \mathrm{SO}_{2} \\
\text { had no significant } \\
\text { effect }\end{array}$ & {$[159]$} \\
\hline $\mathrm{CaCl}_{2}$ & $1.0 \mathrm{wt} \% \mathrm{CaCl}_{2}-\mathrm{SCR}$ & $\begin{array}{c}\text { Physical drying } \\
\text { mixed }\end{array}$ & 78.8 & $\begin{array}{c}41 \mu \mathrm{g} / \mathrm{Nm}^{3} \mathrm{Hg}^{0}, 6 \% \mathrm{O}_{2}, 12 \% \mathrm{CO}_{2} \\
5 \% \mathrm{H}_{2} \mathrm{O}, 1000 \times 10^{-6} \mathrm{SO}_{2}, 300 \times \\
10^{-6} \mathrm{NO}, \mathrm{N}_{2} \text { as balance gas, } \\
\mathrm{SV}=10000 \mathrm{~h}^{-1}, 350{ }^{\circ} \mathrm{C}\end{array}$ & $\begin{array}{c}\text { No significant } \\
\text { effects }\end{array}$ & $\begin{array}{l}\mathrm{Good}_{2} \mathrm{O} \text { resistance, } \\
\mathrm{SO}_{2} \text { slightly promoted } \\
\mathrm{Hg}^{0} \text { oxidation, } \\
\text { no significant effect on } \\
\mathrm{SO}_{2} \text { conversion }\end{array}$ & {$[157]$} \\
\hline $\mathrm{CuCl}_{2}$ & $3 \mathrm{wt} \% \mathrm{CuCl}_{2}-\mathrm{SCR}$ & $\begin{array}{c}\text { Improved } \\
\text { impregnation }\end{array}$ & 88.4 & $\begin{array}{c}7 \mu \mathrm{g} / \mathrm{m}^{3} \mathrm{Hg}^{0}, 20 \times 10^{-6} \mathrm{HCl}, 5 \% \mathrm{O}_{2}, \\
12 \% \mathrm{CO}_{2}, 500 \times 10^{-6} \mathrm{SO}_{2}, 300 \times \\
10^{-6} \mathrm{NO}, 8 \% \mathrm{H}_{2} \mathrm{O}, \mathrm{N}_{2} \text { as balance } \\
\text { gas, GHSV }=3 \times 10^{5} \mathrm{~h}^{-1}, 350{ }^{\circ} \mathrm{C}\end{array}$ & $\begin{array}{l}\text { Reached } 92.1 \% \text { at } \\
350^{\circ} \mathrm{C}\end{array}$ & $\begin{array}{c}250-430{ }^{\circ} \mathrm{C} \mathrm{SO}_{2} \text { and } \\
\mathrm{H}_{2} \mathrm{O} \text { slightly inhibited } \\
\mathrm{Hg}^{0} \text { oxidation }\end{array}$ & {$[158]$} \\
\hline $\mathrm{Ce}$ & $\begin{array}{c}0.8 \mathrm{wt} \% \mathrm{~V}_{2} \mathrm{O}_{5}-8 \mathrm{wt} \% \\
\mathrm{WO}_{3} / \mathrm{TiO}_{2}-\mathrm{CeO}_{2} \\
\text { (molar ratio of } \\
\mathrm{Ce} / \mathrm{Ti}=0.08 \text { ) }\end{array}$ & $\begin{array}{l}\text { Sol-gel and } \\
\text { ultrasound- } \\
\text { assisted } \\
\text { impregnation }\end{array}$ & 88 & $\begin{array}{c}70 \mu \mathrm{g} / \mathrm{m}^{3} \mathrm{Hg}^{0}, 700 \times 10^{-6} \mathrm{NO}, 700 \\
\times 10^{-6} \mathrm{NH}_{3}, 5 \mathrm{vol} \% \mathrm{O}_{2}, 400 \times 10^{-6} \\
\mathrm{SO}_{2}, \mathrm{GHSV}=50000 \mathrm{~h}^{-1}, 250{ }^{\circ} \mathrm{C}\end{array}$ & $\begin{array}{c}\text { Reached } 89 \% \text { at } \\
250{ }^{\circ} \mathrm{C}\end{array}$ & $\begin{array}{l}\text { Good resistances to } \\
\mathrm{SO}_{2} \text { and } \mathrm{H}_{2} \mathrm{O}\end{array}$ & {$[154]$} \\
\hline $\mathrm{Ce}$ & $\begin{array}{c}0.8 \mathrm{wt} \% \mathrm{~V}_{2} \mathrm{O}_{5}-8 \mathrm{wt} \% \\
\mathrm{WO}_{3} / \mathrm{TiO}_{2}-\mathrm{CeO}_{2} \\
\text { (quality ratio of } \\
\mathrm{CeO}_{2} / \mathrm{TiO}_{2}=0.25 \text { ) }\end{array}$ & $\begin{array}{c}\text { Sol-gel and } \\
\text { impregnation }\end{array}$ & 88.93 & $\begin{array}{c}70 \mu \mathrm{g} / \mathrm{m}^{3} \mathrm{Hg}^{0}, 500 \times 10^{-6} \mathrm{SO}_{2}, \\
1000 \times 10^{-6} \mathrm{NO}, 12 \% \mathrm{CO}_{2}, 5 \% \mathrm{O}_{2}, \\
\mathrm{~N}_{2} \text { as balance gas, } \\
\mathrm{GHSV}=1.0 \times 10^{5} \mathrm{~h}^{-1}, 250{ }^{\circ} \mathrm{C}\end{array}$ & - & $\begin{array}{l}\text { Good } \mathrm{H}_{2} \mathrm{O} \text { resistance, } \\
\mathrm{SO}_{2} \text { slightly promoted } \\
\mathrm{Hg}^{0} \text { oxidation }\end{array}$ & {$[155$} \\
\hline $\mathrm{Ce}$ & $\begin{array}{c}1 \mathrm{wt} \% \mathrm{~V}_{2} \mathrm{O}_{5}-10 \mathrm{wt} \% \\
\mathrm{CeO}_{2} / \mathrm{TiO}_{2}\end{array}$ & $\begin{array}{l}\text { Ultra- } \\
\text { sound-assisted } \\
\text { impregnation }\end{array}$ & 81.55 & $\begin{array}{c}60 \mu \mathrm{g} / \mathrm{m}^{3} \mathrm{Hg}^{0}, 5 \text { vol\% } \mathrm{O}_{2}, 500 \times \\
10^{-6} \mathrm{NO}, 500 \times 10^{-6} \mathrm{NH}_{3}, \\
\mathrm{~N}_{2} \text { as balance gas, } \\
\text { GHSV }=65000 \mathrm{~h}^{-1}, 250{ }^{\circ} \mathrm{C}\end{array}$ & $\begin{array}{c}\text { Reached } 91.25 \% \\
\text { at } 300{ }^{\circ} \mathrm{C}\end{array}$ & $\begin{array}{l}\mathrm{SO}_{2} \text { and } \mathrm{H}_{2} \mathrm{O} \text { irreversi- } \\
\text { bly inhibited } \mathrm{SCR} \\
\text { reaction and } \mathrm{Hg}^{0} \\
\text { oxidation }\end{array}$ & $-[156$ \\
\hline $\mathrm{Cu}, \mathrm{Ce}$ & $\begin{array}{c}7 \text { wt } \% \mathrm{Ce}-1 \text { wt } \% \\
\mathrm{Cu} / 1.5 \% \mathrm{~V}_{2} \mathrm{O}_{5}-5 \% \\
\mathrm{MoO}_{3} / \mathrm{TiO}_{2}\end{array}$ & $\begin{array}{l}\text { Ultrasonic- } \\
\text { assisted } \\
\text { impregnation }\end{array}$ & 79.17 & $\begin{array}{c}30 \mu \mathrm{g} / \mathrm{m}^{3} \mathrm{Hg}^{0}, 5 \% \mathrm{O}_{2}, 500 \times 10^{-6} \\
\mathrm{NO}, 500 \times 10^{-6} \mathrm{NH}_{3}, \mathrm{~N}_{2} \text { as balance } \\
\text { gas, GHSV }=45000 \mathrm{~h}^{-1}, 250{ }^{\circ} \mathrm{C}\end{array}$ & $\begin{array}{c}>97 \% \\
\text { at } 200-400{ }^{\circ} \mathrm{C}\end{array}$ & $\begin{array}{c}\mathrm{SO}_{2} \text { and } \mathrm{H}_{2} \mathrm{O} \text { inhibited } \\
\mathrm{Hg}^{0} \text { oxidation }\end{array}$ & {$[160]$} \\
\hline
\end{tabular}

- No data available.

$\mathrm{Y}_{2} \mathrm{O}_{3}, \mathrm{NiO}$, and $\mathrm{ZrO}_{2}$ tend to inhibit this process, while the reverse holds for $\mathrm{Co}_{3} \mathrm{O}_{4}, \mathrm{Fe}_{2} \mathrm{O}_{3}$, and $\mathrm{MnO}_{2}$. Their promotional effects can be ordered as $\mathrm{Fe}_{2} \mathrm{O}_{3}>\mathrm{MnO}_{2}>\mathrm{Co}_{3} \mathrm{O}_{4}$. Overall, $1 \%$ wt $\mathrm{Fe}_{2} \mathrm{O}_{3} / \mathrm{SCR}$ exhibited the best $\mathrm{Hg}^{0}$ oxidation efficiency (>90\%) at $350{ }^{\circ} \mathrm{C}$. Even in the presence of $400 \times 10^{-6} \mathrm{SO}_{2}$, its mercury oxidation effect was only slightly reduced to $80 \%$. $\mathrm{Hg}^{0}$ may be oxidized to $\mathrm{Hg}^{0}$ by $\mathrm{Fe}_{2} \mathrm{O}_{3}$ on the $\mathrm{Fe}_{2} \mathrm{O}_{3} / \mathrm{SCR}$ catalyst surface [149]. When $\mathrm{HCl}$ was added to the flue gas, the intermediate ( $\mathrm{Hg}-\mathrm{OH}-\mathrm{Fe}-\mathrm{Cl}$ ) was generated. Chemisorbed oxygen and $\mathrm{Fe}^{3+}$ would then oxidize $\mathrm{HCl}$ to active chlorine by the Mars-Maessen 


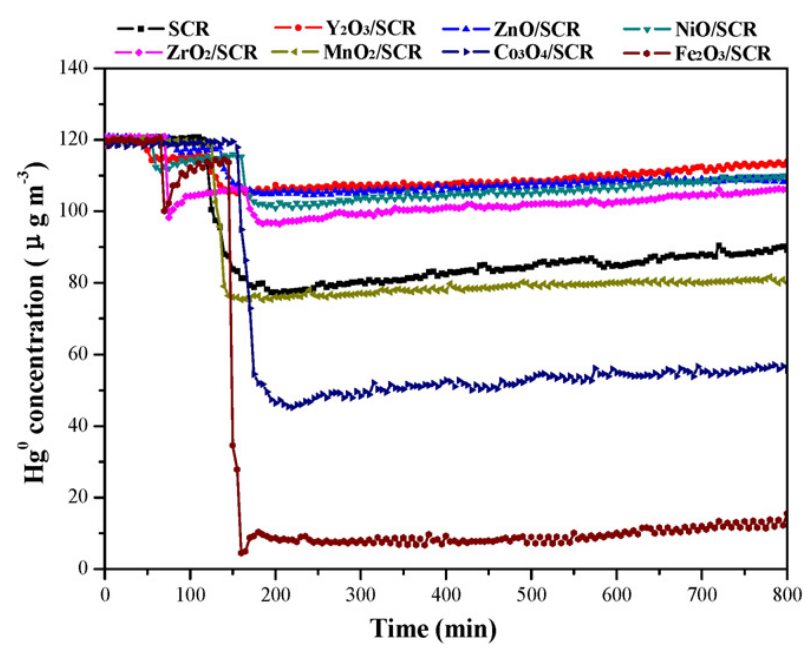

Fig. 8. Comparison of the $\mathrm{Hg}^{0}$ catalytic oxidation efficiencies over various catalysts at $350{ }^{\circ} \mathrm{C}$ [149].

mechanism. Subsequently, the active chlorine then reacted with the adsorbed $\mathrm{HgO}$ and generated $\mathrm{HgCl}_{2}$ by the Langmuir mechanism. This process is presented in Fig. 9. Studies have shown that the $\mathrm{CuO}-\mathrm{V}_{2} \mathrm{O}_{5}-\mathrm{WO}_{3} / \mathrm{TiO}_{2}$ catalyst exhibited excellent $\mathrm{Hg}^{0}$ oxidation properties, even in the absence of $\mathrm{HCl}$. The redox cycle of $\mathrm{V}^{4+}+\mathrm{Cu}^{2+} \leftrightarrow \mathrm{V}^{5+}+\mathrm{Cu}^{+}$would generate abundant chemisorbed oxygen $\left(\mathrm{O}_{\alpha}\right)$, which could oxidize $\mathrm{Hg}^{0}$ into $\mathrm{HgO}$ (Fig. 10) [150].

Ag doping significantly improved the $\mathrm{Hg}^{0}$ catalytic oxidation performance of the vanadium-titanium-based catalyst [151].

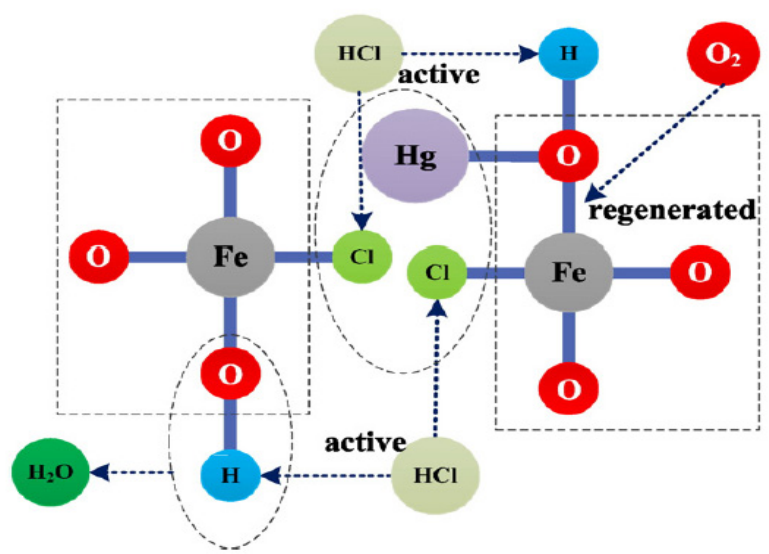

Fig. 9. $\mathrm{Hg}^{0}$ oxidation mechanism on an $\mathrm{Fe}_{2} \mathrm{O}_{3}$ /SCR catalyst [149].

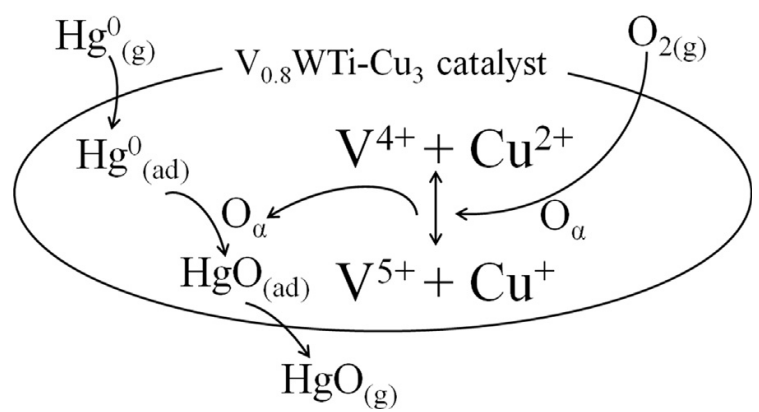

Fig. 10. Schematic diagram of $\mathrm{Hg}^{0}$ oxidation over a $3 \mathrm{wt} \% \mathrm{CuO}-0.8 \mathrm{wt} \%$ $\mathrm{V}_{2} \mathrm{O}_{5}-\mathrm{WO}_{3} / \mathrm{TiO}_{2}$ catalyst [150].
More than $90 \% \mathrm{Hg}^{0}$ can be converted in the simulated flue gas, which contains $5 \times 10^{-6} \mathrm{HCl}$ at $350^{\circ} \mathrm{C}$. This may be attributed to the addition of Ag that weakened the strength of the V-O bond and reduced the desorption activation energy of the surface oxygen species. Vanadium existed in a higher oxidation state so that the oxidation ability of the catalyst was improved and the reaction temperature was reduced. The possible $\mathrm{Hg}^{0}$ oxidation mechanism of this catalyst was also investigated. At low temperatures, amalgamate $\mathrm{Hg}^{0}$ and adsorbed $\mathrm{Hg}^{0}$ reacted with the adsorbed $\mathrm{HCl}$ and formed $\mathrm{HgCl}$, the intermediate before $\mathrm{HgCl}_{2}$ formation. The active chlorine or chlorine atom would also react with gaseous $\mathrm{Hg}$ at high temperatures.

$\mathrm{Ru} / \mathrm{SCR}$ can also increase $\mathrm{Hg}^{0}$ oxidation to $>90 \%$ with the aid of $5 \times 10^{-6} \mathrm{HCl}$ at $350{ }^{\circ} \mathrm{C}$. Yan et al. $[152,153]$ considered the Deacon reaction as its main mechanism. In fact, the Deacon reaction of $\mathrm{RuO}_{2}$ is quite different from that observed for the transition metal oxides (e.g., $\mathrm{MnO}_{2}$ ). The gaseous oxygen is easily adsorbed on the coordinatively unsaturated $\mathrm{Ru}$ site (cus- $\mathrm{Ru}$ ) and activated to reactive oxygen, which then captures hydrogen from $\mathrm{HCl}$. Therefore, $\mathrm{HCl}$ was activated and formed $\mathrm{Cl}_{2}[161,162] . \mathrm{Hg}^{0}$ can be adsorbed at two original cus- $\mathrm{Ru}$ sites and then chlorinated at the cus-Ru sites near the chlorine atoms. Moreover, gaseous $\mathrm{Hg}^{0}$ can even react directly with atomic chlorine. The reaction is as follows [152]:

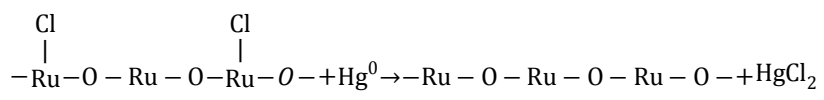

Li et al. [159] modified the commercial SCR catalyst with $\mathrm{Si}$, a common non-metallic element. They suggested that $\mathrm{Hg}^{0}$ oxidation follows the Eley-Rideal mechanism. In this mechanism, $\mathrm{HCl}, \mathrm{NO}$, and $\mathrm{NO}_{2}$ are first adsorbed on the $\mathrm{V}_{2} \mathrm{O}_{5}$ active sites and then react with gaseous $\mathrm{Hg}^{0}$. According to this study, the $\mathrm{SiO}_{2}-\mathrm{TiO}_{2}-\mathrm{V}_{2} \mathrm{O}_{5}$ catalyst revealed a higher $\mathrm{Hg}^{0}$ oxidation efficiency than that observed with $\mathrm{SiO}_{2}-\mathrm{V}_{2} \mathrm{O}_{5}$, possibly because the $\mathrm{V}-\mathrm{O}-\mathrm{Ti}$ bond is more active than the $\mathrm{V}-\mathrm{O}-\mathrm{Si}$ bond. Particularly, in the presence of $10 \times 10^{-6} \mathrm{HCl}$, the maximum $\mathrm{Hg}^{0}$ oxidation efficiency of the prepared catalyst reached $99 \%$ when the weight percentages of $\mathrm{TiO}_{2}$ and $\mathrm{V}_{2} \mathrm{O}_{5}$ were $6 \%$ and $5 \%$, respectively. This demonstrated that non-metallic doping can efficiently improve the mercury oxidation performance and even performs better than widely studied metals. Thus, this process should be studied systematically and deeply.

Since the presence of $\mathrm{HCl}$ plays a vital role in the oxidation of $\mathrm{Hg}^{0}$, researchers have started to select metallic chlorides as modifiers to improve the $\mathrm{Hg}^{0}$ oxidation efficiency of low chlorine coal-fired flue gas. For the $\mathrm{CaCl}_{2}$-SCR catalyst, $1.0 \mathrm{wt} \%$ $\mathrm{CaCl}_{2}$ addition increased the mercury oxidation efficiency from $7.7 \%$ to $78.8 \%$ in the absence of $\mathrm{HCl}$ at $350{ }^{\circ} \mathrm{C}$. $\mathrm{Hg}^{0}$ oxidation could be attributed to both the active chlorine and the $\mathrm{HCl}$ produced by $\mathrm{CaCl}_{2}$ hydrolysis [157]. In general, the active chlorine is considered as an important substance in mercury oxidation by chloride-modified catalysts [163]. Fig. 11 illustrates that gaseous $\mathrm{Hg}^{0}$ would react with active chlorine on the surface and generate gaseous $\mathrm{HgCl}$ with low energy (a); some active chlorine could remove the surface binding and form adsorbed $\mathrm{HgCl}$ if the mercury atom was adsorbed on the active site near 
(a)

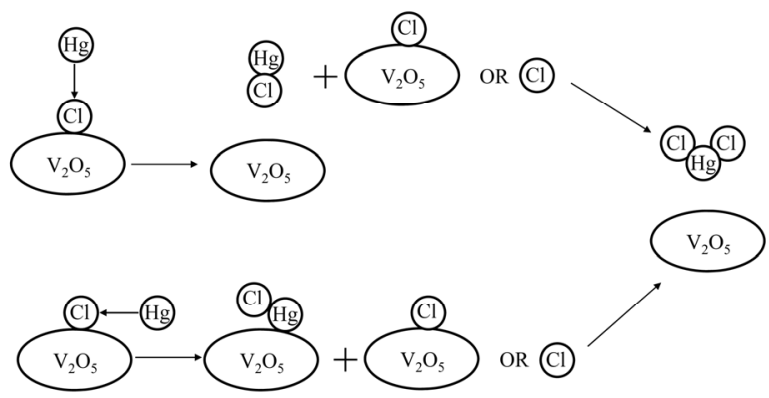

Fig. 11. $\operatorname{Hg}^{0}$ oxidation mechanism on the active surface of the chlorine species [163].

$\mathrm{V}_{2} \mathrm{O}_{5}$ (b). These two types of $\mathrm{HgCl}$ are both oxidized to $\mathrm{HgCl}_{2}$ by active surface chlorine or chlorine atoms and then removed from the surface. Therefore, an increase in active chlorine species could significantly enhance $\mathrm{Hg}^{0}$ oxidation. For the $\mathrm{CuCl}_{2}$-SCR catalysts, both active $\mathrm{Cl}$ species and $\mathrm{Cu}^{2+}$ ions present on its surface played roles in $\mathrm{Hg}^{0}$ oxidation. Fig. 12 illustrates that the $\mathrm{Cl}$ species released by $\mathrm{CuCl}_{2}$ react with the adsorbed $\mathrm{Hg}^{0}$ to form $\mathrm{HgCl}_{2}$, while $\mathrm{CuCl}_{2}$ is reduced to $\mathrm{CuCl}$. The formed $\mathrm{CuCl}$ would react with $\mathrm{O}_{2}$ and generate the intermediate copper oxychloride $\left(\mathrm{Cu}_{2} \mathrm{OCl}_{2}\right)$. This could be re-chlorinated to $\mathrm{CuCl}_{2}$ by the adsorbed $\mathrm{HCl}$ on the catalyst surface when $\mathrm{HCl}$ is added to the flue gas [158]. Therefore, doping of $\mathrm{CuCl}_{2}$ significantly improved the $\mathrm{Hg}^{0}$ oxidation efficiency.

Almost all the studies on $\mathrm{CeO}_{2}$-modified SCR catalysts showed that $>80 \% \mathrm{Hg}^{0}$ efficiency could be achieved in the absence of $\mathrm{HCl}$ [154-156]. $\mathrm{CeO}_{2}$ and $\mathrm{V}_{2} \mathrm{O}_{5}$ would work synergistically in these catalysts. The formed redox cycle of $\mathrm{Ce}^{4+}+\mathrm{V}^{4+} \leftrightarrow$ $\mathrm{Ce}^{3+}+\mathrm{V}^{5+}$ not only greatly improved the NO conversion rate but also promoted $\mathrm{Hg}^{0}$ oxidation. This $\mathrm{Hg}^{0}$ oxidation process follows the Mars-Maessen mechanism, where the adsorbed $\mathrm{Hg}^{0}$ combines with the chemisorbed or lattice oxygen, produced by O-O bond breakage on the $\mathrm{V}_{2} \mathrm{O}_{5}$ surface, and forms the weakly bonded $\mathrm{Hg}-\mathrm{M}-\mathrm{O}_{x-1}(\mathrm{M}=\mathrm{Ce}$ or $\mathrm{V})$. $\mathrm{HgO}$ is generated thereafter (in Fig. 13). The presence of gaseous $\mathrm{O}_{2}$ would promote the regeneration of the lattice and chemically adsorbed oxygen; thus, a reaction cycle is formed. Additionally, $\mathrm{V}_{2} \mathrm{O}_{5}-\mathrm{WO}_{3} / \mathrm{TiO}_{2}-\mathrm{CeO}_{2}$ showed good resistance to $\mathrm{SO}_{2}$ and $\mathrm{H}_{2} \mathrm{O}$ $[154,155]$. On the other hand, the presence of $\mathrm{SO}_{2}$ and $\mathrm{H}_{2} \mathrm{O}$ would reversibly inhibit $\mathrm{NO}$ transformation and $\mathrm{Hg}^{0}$ oxidation over the $\mathrm{V}_{2} \mathrm{O}_{5}-\mathrm{CeO}_{2} / \mathrm{TiO}_{2}$ catalyst and thus, limits its application [156].

The co-modification of $\mathrm{Ce}$ and $\mathrm{Cu}$ was also found to be effective in improving the $\mathrm{Hg}^{0}$ oxidation in the absence of $\mathrm{HCl}$ [160].

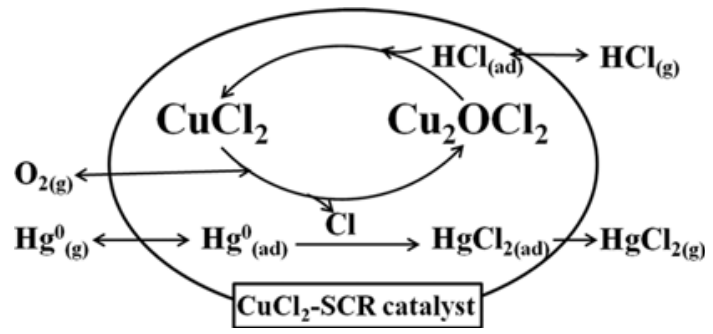

Fig. 12. Schematic diagram of $\mathrm{Hg}^{0}$ oxidation over a $\mathrm{CuCl}_{2}$-SCR catalyst [158].

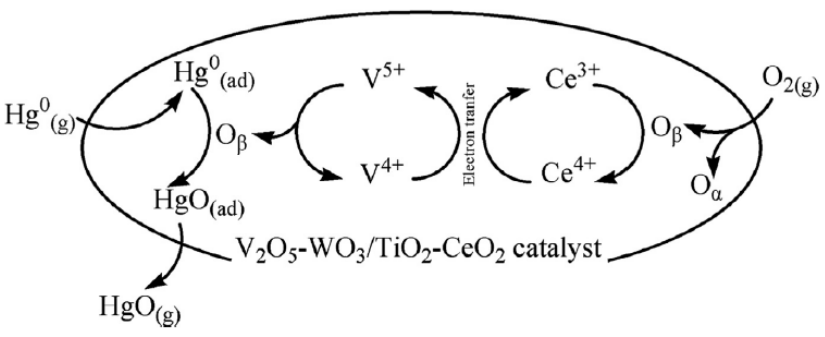

Fig. 13. $\mathrm{Hg}^{0}$ oxidation mechanism of the $\mathrm{V}_{2} \mathrm{O}_{5}-\mathrm{WO}_{3} / \mathrm{TiO}_{2}-\mathrm{CeO}_{2}$ catalyst [155].

These two dopants form the redox cycle $\mathrm{Cu}^{+}+\mathrm{Ce}^{4+} \leftrightarrow \mathrm{Cu}^{2+}+\mathrm{Ce}^{3+}$ in $\mathrm{Ce}-\mathrm{Cu} / \mathrm{SCR}$ catalysts, which promotes the formation of more chemisorbed oxygen and thus, exhibits good redox properties and $\mathrm{Hg}^{0}$ oxidation performance.

Notably, over all these catalysts, ammonia exhibits the most significant inhibitory effect on mercury oxidation, which is similar to the phenomenon observed for traditional SCR catalysts. To some extent, the NO reacted with most of the $\mathrm{NH}_{3}$, thereby reducing this inhibitory effect. However, the slip ammonia that is not consumed in the denitration reaction should be removed to ensure good $\mathrm{Hg}^{0}$ oxidation performance.

\subsection{Oxidizing slip ammonia simultaneously}

It is generally recognized that automotive ammonia can be effectively converted to harmless $\mathrm{N}_{2}$ by dual layer (noble metal-SCR) catalysts $[164,165]$. However, to date, no suitable solution to mitigate slip ammonia from the SCR system of coal-fired power plants has been found. Unfortunately, reducing the $\mathrm{NH}_{3}$ /NO ratio, as the main existing control method, would significantly reduce the deNO $_{x}$ efficiency. Therefore, some researchers have focused on the preparation of new types of catalysts to inhibit slip ammonia while maintaining satisfactory deNO ${ }_{x}$ performance.

Owing to the inherent characteristics of coal-fired flue gas, the catalysts suitable for slip ammonia treatment in power plants require an excellent ammonia conversion efficiency and nitrogen selectivity at high $\mathrm{SO}_{2}$ concentrations and $\sim 350{ }^{\circ} \mathrm{C}$. In general, the temperature of the catalytic decomposition of ammonia is $>500{ }^{\circ} \mathrm{C}$ [166], while the selective catalytic oxidation (SCO) of ammonia requires relatively low temperatures, thus may be an alternative process.

Chen et al. [152] found that a Ru-modified $\mathrm{V}_{2} \mathrm{O}_{5}-\mathrm{WO}_{3} / \mathrm{TiO}_{2}$ catalyst would perform well on slip ammonia oxidation. When installed behind the commercial SCR catalyst, it could effectively oxidize the slip ammonia in the flue gas as keeping a relatively high NO conversion efficiency. Additionally, its $\mathrm{N}_{2}$ selectivity can reach $\sim 90 \%$. The addition of Mo could further promote the ammonia oxidation performance of Ru-SCR catalysts [153]. At $350^{\circ} \mathrm{C}$, the Mo-Ru/SCR catalyst can remove $>95 \%$ slip ammonia, of which $97 \%$ is converted to harmless $\mathrm{N}_{2}$. Its ammonia oxidation efficiency can still reach $>70 \%$ in the presence of $\mathrm{SO}_{2}$. Simultaneously, $>99 \% \mathrm{Hg}^{0}$ could be oxidized when the $\mathrm{HCl}$ concentration in the flue gas was only $5 \times 10^{-6}$. Thus, $\mathrm{Hg}^{0}$, $\mathrm{NH}_{3}$, and $\mathrm{NO}_{x}$ can be efficiently removed simultaneously when a 
Mo-Ru/SCR catalyst is used as a SCR-plus catalyst (Fig. 14).

The unsaturated $\mathrm{Ru}$ (cus- $\mathrm{Ru}$ ) and reactive oxygen species on the $\mathrm{Ru} / \mathrm{SCR}$ catalyst surface play important roles in ammonia oxidation. The $\mathrm{NH}_{3}$ adsorbed on the surface would form the intermediate product with high activity, which is much more easily oxidized (Eqs. (7)-(12) [153]). The addition of Mo further increases the amount of cus-Ru, and thus, promotes the oxidation of slip ammonia.

$$
\begin{gathered}
\mathrm{Ru}_{\text {cus }}-\mathrm{O}^{*}+\mathrm{NH}_{3} \rightarrow \mathrm{Ru}_{\text {cus }}-\mathrm{OH}-\mathrm{NH}_{2} \\
2 \mathrm{Ru}_{\text {cus }}-\mathrm{OH}-\mathrm{NH}_{2} \rightarrow 2 \mathrm{Ru}_{\text {cus }}-\mathrm{NH}_{2}{ }^{*}+\mathrm{H}_{2} \mathrm{O}+\mathrm{O}^{*} \\
2 \mathrm{Ru}_{\text {cus }}-\mathrm{NH}_{2}{ }^{*}+\mathrm{O}_{2} \rightarrow 2 \mathrm{Ru}_{\text {cus }}+\mathrm{N}_{2}+2 \mathrm{H}_{2} \mathrm{O} \\
4 \mathrm{Ru}_{\text {cus }}-\mathrm{NH}_{2} *+3 \mathrm{O}_{2} \rightarrow 4 \mathrm{Ru}_{\text {cus- }}+2 \mathrm{~N}_{2} \mathrm{O}+4 \mathrm{H}_{2} \mathrm{O} \\
\mathrm{Ru}_{\text {cus }}-\mathrm{NH}_{2}{ }^{*}+\mathrm{O}_{2} \rightarrow \mathrm{Ru}_{\text {cus- }}+\mathrm{NO}+\mathrm{H}_{2} \mathrm{O} \\
2 \mathrm{Ru}_{\text {cus }}-\mathrm{NH}_{2}{ }^{*}+3 \mathrm{O}_{2} \rightarrow 2 \mathrm{Ru}_{\text {cus- }}+\mathrm{NO}_{2}+2 \mathrm{H}_{2} \mathrm{O}
\end{gathered}
$$

However, addition of the noble metal ruthenium greatly increases the cost of the catalyst, which is not conducive to commercial application. To date, no other studies of vanadium-titanium-based catalysts for controlling slip ammonia have been reported. Undoubtedly, there are wide areas and great application values to seek more economical and efficient SCO catalysts for slip ammonia from coal-fired power plants.

\subsection{Reducing $\mathrm{SO}_{2}$ oxidation}

In addition to burning low-sulfur coal, mixing coal, and spraying calcium- or magnesium-based absorbents, scholars have tried to control $\mathrm{SO}_{3}$ generation from coal-fired power plants through the modification of commercial SCR catalysts. Changing the physical properties of the catalyst and doping other compounds into the traditional vanadium-titanium-based catalyst can both reduce the $\mathrm{SO}_{2}$ oxidation efficiency.

$\mathrm{DeNO}_{x}$ reaction and $\mathrm{SO}_{2}$ oxidation occur at different parts of the vanadium-based catalysts. According to chemical kinetics studies, the SCR reaction, controlled by external diffusion, mainly occurs in the $0.1-\mathrm{mm}$ surface of the catalyst. On the other hand, the $\mathrm{SO}_{2}$ oxidation process occurs in the whole catalyst and thus, the $\mathrm{SO}_{2}$ conversion rate is proportional to the wall thickness of the SCR catalyst [167]. Therefore, decreasing the wall thickness or using flat catalysts can reduce the formation of $\mathrm{SO}_{3}$ [168]. Others hold that corrugated SCR catalysts may have a lower oxidative effect on $\mathrm{SO}_{2}$ than other shapes of catalysts [169].

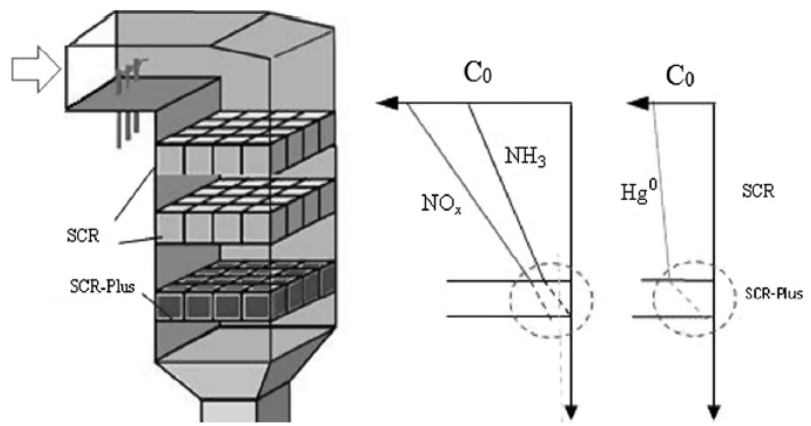

Fig. 14. Mo-Ru/SCR used as an SCR-Plus catalyst and its properties [153].
With the growth of the catalyst service life, the $\mathrm{SO}_{2}$ oxidation rate of SCR catalysts would increase [170]. In addition to $\mathrm{K}_{2} \mathrm{O} / \mathrm{TiO}_{2}$, all the $\mathrm{TiO}_{2}$-loaded metal oxides can oxidize $\mathrm{SO}_{2}$ into $\mathrm{SO}_{3}$. Their $\mathrm{SO}_{2}$ oxidation performance is as follows: $\mathrm{V}_{2} \mathrm{O}_{5} / \mathrm{TiO}_{2}>$ $\mathrm{Fe}_{2} \mathrm{O}_{3} / \mathrm{TiO}_{2}>\mathrm{Re}_{2} \mathrm{O}_{7} / \mathrm{TiO}_{2}>\mathrm{CrO}_{3} / \mathrm{TiO}_{2}>\mathrm{Nb}_{2} \mathrm{O}_{5} / \mathrm{TiO}_{2}>$ $\mathrm{MoO}_{3} / \mathrm{TiO}_{2}>\mathrm{WO}_{3} / \mathrm{TiO}_{2}$ [171]. Since $\mathrm{V}_{2} \mathrm{O}_{5} / \mathrm{TiO}_{2}$ displays a strong $\mathrm{SO}_{2}$ oxidation ability [114], reducing the vanadium content in the SCR catalyst can inhibit $\mathrm{SO}_{3}$ generation; however, the deNO ${ }_{x}$ efficiency will also significantly decrease [171].

As early as 1981, Morikawa et al. [172] have studied the $\mathrm{SO}_{2}$ oxidation of vanadium-titanium-based catalysts doped with metal oxides. Their oxidation activities are of the order of: $\mathrm{WO}_{3}-\mathrm{V}_{2} \mathrm{O}_{5}-\mathrm{TiO}_{2}>\mathrm{MoO}_{3}-\mathrm{V}_{2} \mathrm{O}_{5}-\mathrm{TiO}_{2}>\mathrm{V}_{2} \mathrm{O}_{5}-\mathrm{TiO}_{2}>$ $\mathrm{Ta}_{2} \mathrm{O}_{5}-\mathrm{V}_{2} \mathrm{O}_{5}-\mathrm{TiO}_{2}>\mathrm{Y}_{2} \mathrm{O}_{3}-\mathrm{V}_{2} \mathrm{O}_{5}-\mathrm{TiO}_{2}>\mathrm{GeO}_{2}-\mathrm{V}_{2} \mathrm{O}_{5}-\mathrm{TiO}_{2}>$ $\mathrm{ZnO}-\mathrm{V}_{2} \mathrm{O}_{5}-\mathrm{TiO}_{2}$. Thus, $\mathrm{WO}_{3}$ or $\mathrm{MoO}_{3}$ doping can enhance the $\mathrm{SO}_{2}$ oxidation of vanadium-titanium-based catalysts, while $\mathrm{GeO}_{2}$ and $\mathrm{ZnO}$ would inhibit it. Some studies have suggested that tungsten can promote $\mathrm{SO}_{2}$ oxidation $[173,174]$. However, others argue that doping with $\mathrm{WO}_{3}$ or $\mathrm{MoO}_{3}$ would increase the surface acidity, which can effectively reduce the $\mathrm{SO}_{2}$ conversion rate [175]. When the loading mass fraction of $\mathrm{MoO}_{3}$ is $>9 \%$, the $\mathrm{SO}_{2}$ conversion rate could be $<1 \%$ [176]. Moreover, the decomposition of $\mathrm{NH}_{4} \mathrm{HSO}_{4}$ can be markedly enhanced by $\mathrm{WO}_{3}$ doping, which promotes the reaction of $\mathrm{NH}_{4} \mathrm{HSO}_{4}$ and $\mathrm{NO}$ and inhibits $\mathrm{N}_{2} \mathrm{O}$ production during the reaction [177].

Shi et al. $[178,179]$ doped the transition metal $\mathrm{Cu}$ into a traditional SCR catalyst. A $0.6 \%$ addition reduced the $\mathrm{SO}_{2}$ conversion rate from $0.73 \%$ to $0.68 \%$, while maintaining a denitrification efficiency of $94.47 \%$. They found that the amount of $\mathrm{V}^{4+}$ ions in the doped catalyst increased, while those of the $\mathrm{V}^{5+}$ ions and lattice oxygen decreased. This may abate the transfer of lattice oxygen, thereby inhibiting $\mathrm{SO}_{2}$ oxidation. Theoretical calculations have shown that the oxygen charge in the V-O-M oxygen bridge changed from negative to positive in Me-doped catalysts. This indicated that the basicity of oxygen decreased and thus, $\mathrm{SO}_{2}$ oxidation was inhibited.

$\mathrm{Li}$ et al. [180] found that doping $\mathrm{BaO}, \mathrm{MgO}, \mathrm{SrO}$, and their mixtures would reduce the $\mathrm{SO}_{2} / \mathrm{SO}_{3}$ conversion rate of the SCR catalysts in high-sulfur flue gas, wherein the $\mathrm{SO}_{2}$ oxidation rate of $\mathrm{BaO}$ addition is the lowest. Adding $\mathrm{SiO}_{2}$ into the three single-doped catalysts can significantly improve the denitrification efficiency, which is originally slightly reduced. Their $\mathrm{SO}_{2}$ oxidation rate was only $\sim 0.5 \%$, while the denitrification efficiency was $>80 \%$ at $300-440{ }^{\circ} \mathrm{C}$. Some studies found that vanadium tended to be present in a lower oxidation state when $\mathrm{BaO}$ [181] or $\mathrm{SiO}_{2}[173,174,182]$ was added. The redox capacity and $\mathrm{SO}_{2}$ adsorption sites were also reduced and thus, $\mathrm{SO}_{2}$ oxidation was inhibited. For example, the $\mathrm{V}_{2} \mathrm{O}_{5}-\mathrm{BaO} / \mathrm{TiO}_{2}$ catalyst, which contains $2 \% \mathrm{BaO}$, showed less than half the $\mathrm{SO}_{2}$ oxidation efficiency of an unmodified or tungsten-added catalyst. Further, when the $\mathrm{Ti} / \mathrm{Si}$ molar ratio in the $\mathrm{V}_{2} \mathrm{O}_{5} / \mathrm{TiO}_{2}-\mathrm{SiO}_{2}$ catalyst was $8 / 2$, a high deNO ${ }_{x}$ efficiency was maintained, while the $\mathrm{SO}_{2}$ conversion was only about a third of that of the $\mathrm{V}_{2} \mathrm{O}_{5} / \mathrm{TiO}_{2}$ catalyst [174].

Rare earth, niobium, and silicon-aluminum composite oxides have also been used simultaneously as additives of vanadium, titanium, and tungsten to prepare a new catalyst for low $\mathrm{SO}_{3}$ generation [183]. This prepared catalyst showed the same 
deNO ${ }_{x}$ activity as the conventional SCR catalyst, while the $\mathrm{SO}_{2}$ oxidation rate was reduced by $20 \%-40 \%$. However, its inhibitory mechanism has not been revealed.

In general, doping of the oxidizing substances can improve the $\mathrm{Hg}^{0}$ and slip $\mathrm{NH}_{3}$ oxidation efficiency of the SCR catalyst. However, $\mathrm{SO}_{2}$ oxidation may also be promoted. This will lead to catalyst poisoning, thereby causing a reduction in the $\mathrm{Hg}^{0}$ and $\mathrm{NO}_{x}$ removal efficiencies. However, the additives that inhibit $\mathrm{SO}_{2}$ oxidation tend to reduce the oxidation properties of the catalysts. Moreover, $\mathrm{NH}_{3}$ oxidation is an adverse reaction of the SCR process, which may reduce the denitrification efficiency. Therefore, both the oxidation capacity and the selectivity of the catalysts should be taken into account when choosing the appropriate modified compounds. As a result, it is rather complicated to inhibit $\mathrm{SO}_{2}$ oxidation while efficiently reducing $\mathrm{NO}_{x}$, oxidizing mercury, and slip ammonia at the same time. A comprehensive selection of catalyst formulations and preparation methods should therefore be made.

\subsection{Increasing alkali resistance}

Studies have shown that alkali metals in the flue gas would deposit on the surface of the catalysts used in coal-fired power plants [184]. This can lead to catalyst deactivation when these substances are in excess $[185,186]$. These alkali metals would significantly decrease both the surface acidity and reducibility of the vanadium-titanium-based catalysts, change the $\mathrm{V}=0$ groups, and thus, inhibit the SCR reaction [185,187,188].

Fortunately, the modification of ceria would improve the alkali poisoning resistance of the $\mathrm{V}_{2} \mathrm{O}_{5}-\mathrm{WO}_{3} / \mathrm{TiO}_{2}$ catalyst. Fig. 15 reveals that the deNO $\mathrm{O}_{x}$ activity of $\mathrm{V}_{2} \mathrm{O}_{5}-\mathrm{CeO}_{2}-\mathrm{WO}_{3} / \mathrm{TiO}_{2}$ was much higher, even after doping with $\mathrm{K}$ and $\mathrm{Na}$ [185]. This phenomenon may be due to the good oxygen storage capacity of ceria and the high reducibility produced by the redox properties of $\mathrm{Ce}^{4+}$ to $\mathrm{Ce}^{3+}$. Additionally, the adsorption amount of alkali metals on the active $\mathrm{V}$ species was reduced since the $\mathrm{K}$ or $\mathrm{Na}$ atoms would easily bond to the $\mathrm{CeO}_{2}$ (110) surface [187]. The co-doping of $\mathrm{Sb}$ and $\mathrm{Nb}$ can also enhance the $\mathrm{K}_{2} \mathrm{O}$ poisoning resistance of the $\mathrm{V}_{2} \mathrm{O}_{5} / \mathrm{TiO}_{2}$ catalyst. The $\mathrm{K}_{2} \mathrm{O}$-doped 1 wt $\%$

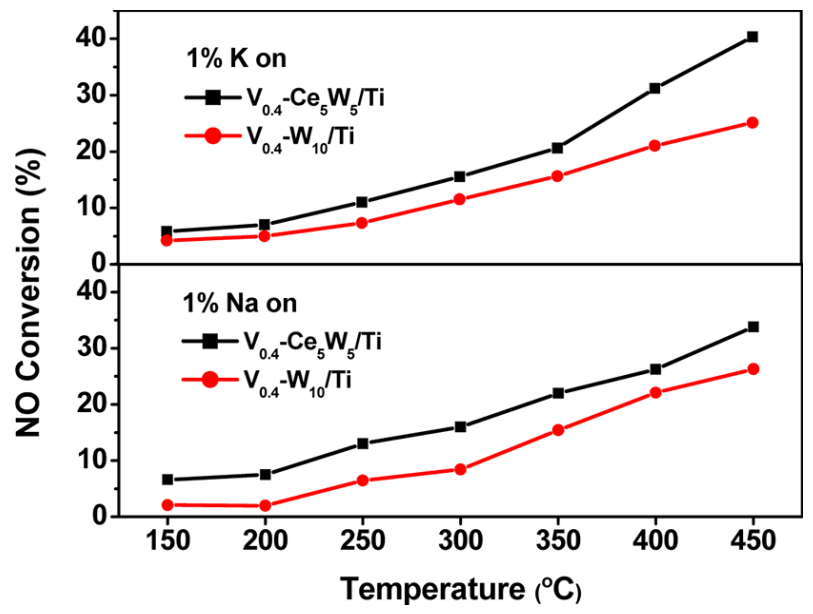

Fig. 15. Activity of $1 \%$ alkali-doped $\mathrm{V}_{0.4}-\mathrm{Ce}_{5} \mathrm{~W}_{5} / \mathrm{Ti}$ and $\mathrm{V}_{0.4}-\mathrm{W}_{10} / \mathrm{Ti}$ catalysts [185].
$\mathrm{V}_{2} \mathrm{O}_{5}-\mathrm{Sb}-\mathrm{Nb} / \mathrm{TiO}_{2}$ (atomic ratio of $\mathrm{Sb} / \mathrm{V}=0.5, \mathrm{Nb} / \mathrm{V}=1$ ) catalyst even demonstrated higher deNO $_{x}$ performance than fresh vanadium-titanium catalysts [189]. However, the relevant mechanism was not explained in this study. Moreover, the addition of $\mathrm{Nb}$ possibly facilitated the dissociation of water, which generated surface hydroxyl species and increased the surface acidity. Therefore, the $\mathrm{V}_{2} \mathrm{O}_{5}-\mathrm{Sb}-\mathrm{Nb} / \mathrm{TiO}_{2}$ catalyst showed higher water resistance than the vanadium-titanium catalysts.

In fact, compared to the study of the $\mathrm{SO}_{2}$ and $\mathrm{H}_{2} \mathrm{O}$ resistances of the catalysts, the influence of alkali metal poisoning has rarely been investigated. This could be a promising research direction for the industrial application of SCR catalysts.

\subsection{Others}

In addition to the above five types of catalysts, some other modified catalysts have also been studied. For example, modification by Mn [190], Si [191], nanotubes [192], and cordierite supports [14] would further increase the denitrification activity; low-cost Fe [193,194] and $\mathrm{Cu}[195]$ enhance $\mathrm{N}_{2}$ selectivity; addition of $\mathrm{BaSO}_{4}$ [196] improves the $\mathrm{SO}_{2}$ resistance; and cordierite-loaded SCR catalysts [14] possess excellent mechanical strength and wash coating stability. These catalysts are summarized in Table 5.

\section{Conclusions}

Although for several years, new types of SCR catalysts have aroused great interest, vanadium-titanium-based catalysts remain unchallenged owing to their excellent performance and experience in application. However, their low-temperature deNO $_{x}$ efficiency, thermal stability, and synergistic mercury oxidation performance, still leaves much to be desired and the problems of $\mathrm{SO}_{2}$ oxidation and ammonia slip need to be urgently addressed.

By doping different materials such as noble metals (e.g. Ag, $\mathrm{Ru}$ ), transition metals (e.g. $\mathrm{Mn}, \mathrm{Fe}, \mathrm{Cu}, \mathrm{Zr}$, etc.), rare earth metals (e.g. $\mathrm{Ce}, \mathrm{Pr}$ ), and other metal chlorides (e.g. $\mathrm{CaCl}_{2}, \mathrm{CuCl}_{2}$ ) and non-metals (F, S, Si, N, etc.), these modified vanadium-titanium catalysts have been proven to exhibit a corresponding promoted performance. Their reported advantages and disadvantages are summarized in Table 6.

In fact, owing to equipment and experimental condition limitations, the $\mathrm{N}_{2} \mathrm{O}$ selectivity of many of these catalysts was not considered in previous studies, and the impact of flue gas composition such as $\mathrm{SO}_{2}$ and $\mathrm{H}_{2} \mathrm{O}$ on the catalyst properties is still unclear. Further studies on their shortcomings and practicality are also needed.

\section{Perspectives}

In summary, more studies are needed to further improve the comprehensive performance of modified vanadium-titanium-based SCR catalysts to adapt to various operating conditions in coal-fired power plants. Future research may involve the following aspects:

(1) Great effort should be made to explore vanadi- 
Table 5

Other modified SCR catalysts and their properties.

\begin{tabular}{|c|c|c|c|c|c|c|c|c|}
\hline $\begin{array}{l}\text { Modified } \\
\text { components }\end{array}$ & Catalyst & $\begin{array}{l}\text { Preparation } \\
\text { method }\end{array}$ & $\begin{array}{l}\text { Tempera- } \\
\text { ture }\left({ }^{\circ} \mathrm{C}\right)\end{array}$ & $\begin{array}{c}\mathrm{DeNO}_{x} \\
\text { efficiency }\end{array}$ & $\begin{array}{l}\mathrm{N}_{2} \text { selectiv- } \\
\text { ity }(\%)\end{array}$ & $\begin{array}{c}\text { Active temper- } \\
\text { ature window } \\
\left({ }^{\circ} \mathrm{C}\right)\end{array}$ & $\begin{array}{l}\text { Anti-poisoning } \\
\text { performance }\end{array}$ & Ref. \\
\hline Mn & $1 \mathrm{wt} \% \mathrm{~V}_{2} \mathrm{O}_{5}-2 \mathrm{wt} \% \mathrm{MnO}_{2} / \mathrm{TiO}_{2}$ & Impregnation & $300-400$ & $>90$ & $\sim 100$ & $275-425$ & $\begin{array}{l}\text { Inhibitions of } \mathrm{SO}_{2} \text { and } \\
\mathrm{H}_{2} \mathrm{O} \text { were reversible. }\end{array}$ & [190] \\
\hline $\mathrm{Si}$ & $\begin{array}{l}\mathrm{Si}-1 \text { wt } \% \mathrm{~V}_{2} \mathrm{O}_{5} / \mathrm{TiO}_{2} \text { (mole } \\
\text { ratio of } \mathrm{Si} / \mathrm{Ti}=0.2 \text { ) }\end{array}$ & $\begin{array}{c}\text { Sol-gel and } \\
\text { impregnation }\end{array}$ & 300 & $>94$ & - & $300-400$ & $\begin{array}{c}\text { Showed better } \mathrm{H}_{2} \mathrm{O} \text { and } \\
\mathrm{SO}_{2} \text { resistances than } \\
\mathrm{V}_{2} \mathrm{O}_{5} / \mathrm{TiO}_{2}\end{array}$ & [191] \\
\hline Nanotube & $\begin{array}{l}3 \mathrm{wt} \% \mathrm{~V}_{2} \mathrm{O}_{5}-10 \mathrm{wt} \% \\
\mathrm{wO}_{3} / \mathrm{TiO}_{2} \text {-nanotube }\end{array}$ & Sol-gel & 380 & $>93$ & - & $300-400$ & $\begin{array}{c}\text { Good } \mathrm{SO}_{2} \text { resistance, } \mathrm{H}_{2} \mathrm{O} \\
\text { slightly inhibited the } \\
\text { deNO } \\
\text { efficiency. }\end{array}$ & [192] \\
\hline Cordierite & $\begin{array}{c}0.9 \mathrm{wt}^{2} \mathrm{~V}_{2} \mathrm{O}_{5}-7.2 \mathrm{wt} \% \\
\mathrm{MoO}_{3} / \mathrm{TiO}_{2} / \text { Monolithic } \\
\text { cordierite }\end{array}$ & $\begin{array}{l}\text { Sol-gel and } \\
\text { impregnation }\end{array}$ & 400 & 98 & $\sim 95$ & $300-500$ & $\begin{array}{c}\mathrm{SO}_{2} \text { and } \mathrm{H}_{2} \mathrm{O} \text { resistances } \\
\text { were }>90 \% \text { at } \\
350-450{ }^{\circ} \mathrm{C}\end{array}$ & [14] \\
\hline $\mathrm{Fe}$ & $\begin{array}{l}8 \mathrm{wt} \% \mathrm{Fe}-\mathrm{ZSM}-5 \text { zeolite- } 1.68 \\
\mathrm{wt} \% \mathrm{~V}_{2} \mathrm{O}_{5}-7.6 \mathrm{wt} \% \mathrm{WO}_{3} / \mathrm{TiO}_{2}\end{array}$ & $\begin{array}{l}\text { Solid-state } \\
\text { sublimation } \\
\text { technique }\end{array}$ & $300-500$ & $>78$ & $>97$ & $300-450$ & - & [193] \\
\hline $\mathrm{Fe}$ & $\begin{array}{c}2 \mathrm{wt} \% \mathrm{~V}_{2} \mathrm{O}_{5} / \mathrm{Fe}_{2} \mathrm{O}_{3}-\mathrm{TiO}_{2} \\
\left(\mathrm{Fe}^{2+}: \mathrm{Fe}^{3+}: \mathrm{Ti}^{4+}=3: 2: 1\right)\end{array}$ & $\begin{array}{l}\text { Co-precipitation } \\
\text { and impregnation }\end{array}$ & $300-450$ & $>90$ & $>95$ & $300-450$ & $\begin{array}{l}\text { Good } \mathrm{H}_{2} \mathrm{O} \text { and } \mathrm{SO}_{2} \\
\text { resistances }\end{array}$ & [194] \\
\hline $\mathrm{Cu}$ & 4 wt $\% \mathrm{Cu}-6 \mathrm{wt} \% \mathrm{~V} / \mathrm{TiO}_{2}$ & Co-impregnation & $225-375$ & $>85$ & $>95$ & $225-375$ & $\begin{array}{l}\text { Showed good stability } \\
\text { and } \mathrm{SO}_{2} / \mathrm{H}_{2} \mathrm{O} \text { resistance }\end{array}$ & [195] \\
\hline $\mathrm{BaSO}_{4}$ & $\begin{array}{c}\text { Sulfurated } 1 \text { wt } \% \\
\mathrm{~V}_{2} \mathrm{O}_{5} / \mathrm{BaSO}_{4}-\mathrm{TiO}_{2} \text { (weight ratio } \\
\text { of } \mathrm{BaSO}_{4}: \mathrm{TiO}_{2}=2.5: 97.5 \text { ) }\end{array}$ & $\begin{array}{l}\text { Incipient wetness } \\
\text { impregnation }\end{array}$ & $300 / 400$ & $85 / 96$ & $100 / 98$ & $350-450$ & Excellent $\mathrm{SO}_{2}$ resistance & [196] \\
\hline
\end{tabular}

Table 6

Summary of the main modified vanadium-titanium-based SCR catalysts.

\begin{tabular}{|c|c|c|c|c|}
\hline Catalyst system & $\begin{array}{l}\text { Doping } \\
\text { elements }\end{array}$ & Advantages & Disadvantages & Ref. \\
\hline $\begin{array}{l}\text { Noble metal-modified SCR } \\
\text { catalysts }\end{array}$ & $\mathrm{Ag}, \mathrm{Ru}$ & 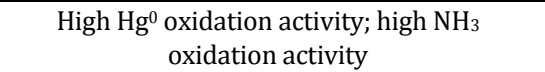 & High cost & e.g. [151-153] \\
\hline \multirow{3}{*}{$\begin{array}{l}\text { Transition metal-modified } \\
\text { SCR catalysts }\end{array}$} & $\mathrm{Cu}, \mathrm{Fe}, \mathrm{Mn}$ & $\begin{array}{l}\text { High low-temperature } \mathrm{NH}_{3} \text {-SCR activity; } \\
\text { high } \mathrm{Hg}^{0} \text { oxidation activity }\end{array}$ & - & $\begin{array}{l}\text { e.g. }[100-103,149,150,160 \text {, } \\
\quad 178,179,190,193-195]\end{array}$ \\
\hline & $\mathrm{Zr}$ & $\begin{array}{l}\text { High low-temperature } \mathrm{NH}_{3}-\mathrm{SCR} \text { activity; } \\
\text { high thermal stability }\end{array}$ & - & e.g. $[94,95,98,125]$ \\
\hline & $\mathrm{Nb}$ & $\begin{array}{l}\text { high } \mathrm{H}_{2} \mathrm{O} \text { resistance; Good alkali poisoning } \\
\text { resistance }\end{array}$ & - & e.g. [189] \\
\hline $\begin{array}{l}\text { Rare earth-modified SCR } \\
\text { catalysts }\end{array}$ & $\mathrm{Ce}, \mathrm{Pr}, \mathrm{Er}$ & $\begin{array}{l}\text { High low-temperature } \mathrm{NH}_{3} \text {-SCR activity; high } \\
\text { thermal stability; high } \mathrm{Hg}^{0} \text { oxidation activity; } \\
\text { good alkali poisoning resistance }\end{array}$ & - & $\begin{array}{l}\text { e.g. }[87,91-99,120-122, \\
124,154-156,160,185]\end{array}$ \\
\hline $\begin{array}{l}\text { Metal chloride-modified } \\
\text { SCR catalysts }\end{array}$ & $\mathrm{CaCl}_{2}, \mathrm{CuCl}_{2}$ & High $\mathrm{Hg}^{0}$ oxidation activity & - & e.g. $[157,158]$ \\
\hline $\begin{array}{l}\text { Alkali-modified SCR } \\
\text { catalysts }\end{array}$ & K & High thermal stability & $\begin{array}{l}\text { Cause deactivation of the } \\
\text { catalyst }\end{array}$ & e.g. $[127,185-189]$ \\
\hline \multirow{2}{*}{$\begin{array}{l}\text { Alkaline earth met- } \\
\text { al-modified SCR catalysts }\end{array}$} & $\mathrm{Ba}$ & Low $\mathrm{SO}_{2}$ oxidation & $\begin{array}{l}\text { Low } \mathrm{NO}_{x} \text { removal activity; } \\
\text { low thermal stability }\end{array}$ & e.g. $[126,180,181,196]$ \\
\hline & $\mathrm{Sr}, \mathrm{Mg}$ & Low $\mathrm{SO}_{2}$ oxidation & Low $\mathrm{NO}_{x}$ removal activity & e.g. $[180]$ \\
\hline $\begin{array}{l}\text { Pnictogen-modified SCR } \\
\text { catalyst }\end{array}$ & $\mathrm{Sb}$ & $\begin{array}{l}\text { High } \mathrm{SO}_{2} \text { resistance; Good alkali poisoning } \\
\text { resistance }\end{array}$ & - & e.g. $[93,97,106,189]$ \\
\hline $\begin{array}{l}\text { Carbon element-modified } \\
\text { SCR catalyst }\end{array}$ & Ge & Low $\mathrm{SO}_{2}$ oxidation & - & e.g. [172] \\
\hline & $\mathrm{F}, \mathrm{N}, \mathrm{S}$ & High low-temperature $\mathrm{NH}_{3}$-SCR activity; & - & e.g. $[107-113,115]$ \\
\hline $\begin{array}{l}\text { Non-metallic modified SCR } \\
\text { catalysts }\end{array}$ & $\mathrm{Si}$ & $\begin{array}{l}\text { high low-temperature } \mathrm{NH}_{3} \text {-SCR activity; high } \\
\text { thermal stability; high } \mathrm{Hg}^{0} \text { oxidation activity; } \\
\qquad \text { low } \mathrm{SO}_{2} \text { oxidation }\end{array}$ & - & $\begin{array}{l}\text { e.g. }[119,120,159,173, \\
\qquad 174,182,191]\end{array}$ \\
\hline
\end{tabular}

um-titanium-based catalysts with high deNO $\mathrm{N}_{x}$ performance, high $\mathrm{N}_{2}$ selectivity, good $\mathrm{SO}_{2}$ and $\mathrm{H}_{2} \mathrm{O}$ resistance, and a wide operating temperature window. Considering both catalytic activity and cost, transition metal oxides, rare earth metal ox- ides, and non-metallic elements are still the main modifiers. Moreover, modification of the carrier is also a possible research direction.

(2) As the key to the synergistic control of mercury pollution 


\section{Graphical Abstract}

Chin. J. Catal., 2018, 39: 1347-1365 doi: 10.1016/S1872-2067(18)63090-6

Review on the latest developments in modified vanadium-titanium-based SCR catalysts

Chuanmin Chen *, Yue Cao, Songtao Liu, Jianmeng Chen, Wenbo Jia

North China Electric Power University

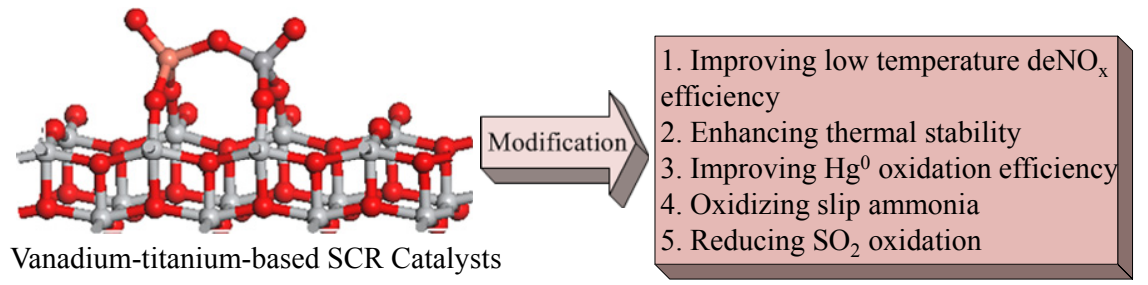

Commercial vanadium-titanium-based SCR catalysts were doped with some modified components to obtain higher thermal stability, low-temperature $\mathrm{NH}_{3}-\mathrm{SCR}$ and $\mathrm{Hg}^{0}$ oxidation activity, and reduce slip ammonia and $\mathrm{SO}_{3}$ generation.

by SCR catalysts, $\mathrm{Hg}^{0}$ oxidation performance and its enhancing method should be thoroughly investigated. Moreover, slip ammonia in the tail of the SCR system significantly inhibits $\mathrm{Hg}^{0}$ oxidation. The reaction of slip ammonia and the generated $\mathrm{SO}_{3}$ would affect the stable operation of the catalyst and the downstream flue gas equipment and should therefore be inhibited. Much effort should be made to realize the cooperative control of multiple pollutants in the SCR system.

(3) Mechanisms affecting the catalytic properties of the modified constituents should be revealed. Many experimental results have shown that doping suitable metallic oxides and non-metallic elements can significantly enhance the $\mathrm{NH}_{3}-\mathrm{SCR}$ performance of vanadium-titanium-based SCR catalysts. This is attributed to many aspects, including a larger surface area, increased acidic sites, and added surface oxygen. However, their detailed mechanisms are still unclear. The mechanism of mercury oxidation and poisoning of vanadium-titanium-based SCR catalysts should also be studied intensively. Moreover, blind experimental screens would waste resources and research efforts, which could be avoided by theoretical calculation of possible modified components.

(4) Larger pilot tests are also needed to develop modified SCR catalysts suitable for commercial application. To date, most of the catalysts and the flue gas produced at the laboratory level are somewhat different from the actual situation, and thus, there is insufficient data to exhibit the actual effect of the catalysts in practical applications. Studies that more closely simulate the actual industrial conditions are needed to further investigate the value of using these catalysts.

\section{References}

[1] H. Bosch, F. Janssen, Catal. Today, 1988, 2, 369-521.

[2] Y. Shi, Y. Xia, B. Lu, N. Liu, L. Zhang, S. Li, W. Li, J. Zhejiang Univ-Sci. A, 2014, 15, 454-464.

[3] R. K. Srivastava, W. Neuffer, D. Grano, S. Khan, J. Staudt, W. Jozewicz, Environ. Progr., 2010, 24, 181-197.
[4] D. Yang, Q. Chen, Appl. Mech. Mater., 2014, 535,131-134.

[5] R. A. Pandey, B. Chandrashekhar, Crit. Rev. Environ. Sci. Technol., 2014, 44, 34-96.

[6] J. Hitchins, R. Wolff, D. Gilbert, Atomos. Environ., 2000, 34, 51-59.

[7] F. Luck, J. Roiron, Catal. Today, 1989, 4, 205-218.

[8] Z. Zhu, Z. Liu, S. Liu, H. Niu, T. Hu, T. Liu, Y. Xie, Appl. Catal. B, 2000, $26,25-35$.

[9] Z. G. Lei, C. P. Wen, B. H. Chen, Environ. Sci. Technol,, 2011, 45, 3437-3444.

[10] V. I. Pârvulescu, P. Grange, B. Delmon, Catal. Today, 1998, 46, 233-316.

[11] Y. Peng, W. Z. Si, X. Li, J. M. Luo, J. H. Li, J. Crittenden, J. M. Hao, Appl. Catal. B, 2016, 181, 692-698.

[12] S. M. Lee, K. H. Park, S. C. Hong, Chem. Eng. J., 2012, 195-196, 323-331.

[13] M. D. Amiridis, R. V. Duevel, I. E. Wachs, Appl. Catal. B, 1999, 20, 111-122.

[14] Y. Qiu, B. Liu, J. Du, Q. Tang, Z. H. Liu, R. L. Liu, C. Y. Tao, Chem. Eng. J., 2016, 294, 264-272.

[15] M. Shimokawabe, A. Kuwana, S. Oku, K. Yoshida, M. Arai, Catal. Today, 2011, 164, 480-483.

[16] S. S. Kim, S. H. Choi, S. M. Lee, S. C. Hong, J. Ind. Eng. Chem., 2012, $18,272-276$

[17] I. Salem, X. Courtois, E. C. Corbos, P. Marecot, D. Duprez, Catal. Commun., 2008, 9, 664-669.

[18] Y. Geng, W. D. Shan, S. C. Xiong, Y. Liao, S. J. Yang, F. D. Liu, Catal. Sci. Technol., 2015, 6, 3149-3155.

[19] L. M. Yu, Q. Zhong, Z. Y. Deng, S. L. Zhang, J. Mol. Catal. A, 2016, 423, 371-378.

[20] X. Liu, P. Ning, H. Li, Z. Song, Y.C. Wang, J. Zhang, X. Tang, M. Wang, Q. Zhang, J. Fuel Chem. Technol, 2016, 44, 225-231.

[21] C. Z. Shao, X. F. Liu, D. M. Meng, Q. Xu, Y. L. Guo, Y. Guo, W. C. Zhan, L. Wang, G. Z. Lu, RSC Adv., 2016, 6, 66169-66179.

[22] N. Yang, R. T. Guo, Q. Wang, W. Pan, Q. Chen, C. Lu, S. Wang, RSC Adv., 2016, 6, 11226-11232.

[23] H. Liang, K. T. Gui, X. B. Zha, Can. J. Chem. Eng., 2016, 94, 1668-1675.

[24] D. J. Yan, Y. Xu, X. M. Huang, Y. Yu, S. J. Liu, J. Environ. Sci., 2015, 35, 1697-1702.

[25] C. Tyrsted, E. Borfecchia, G. Berlier, K. A. Lomachenko, C. Lamberti, 
S. Bordiga, P. N. R. Vennestrøm, T. V. W. Janssens, H. Falsig, P. Beato, A. Puig-Molina, Catal. Sci. Technol., 2016, 6, 8314-8324.

[26] F. X. Zhang, S. J. Zhang, N. J. Guan, E. Schreier, M. Richter, R. Eckelt, R. Fricke, Appl. Catal. B, 2007, 73, 209-219.

[27] K. A. Lomachenko, E. Borfecchia, C. Negri, G. Berlier, C. Lamberti, P. Beato, H. Falsig, S. Bordiga, J. Am. Chem. Soc., 2016, 138, 12025-12028.

[28] G. Y. Xu, Y. T. Wang, Y. Yang, Y. Fu, X. Gou, J. Wu, Adv. Eng. Res., 2016, 49, 418-421.

[29] R. Q. Long, R. T. Yang, R. Chang, Chem. Commun., 2002, 5, 452-453.

[30] Z. M. Liu, Y. X. Liu, B. H. Chen, T. L. Zhu, L. L. Ma, Catal. Sci. Technol,, 2016, 6, 6688-6696.

[31] X. Zhao, L. Huang, H. R. Li, H. Hu, X. N. Hu, L. Y. Shi, D. S. Zhang, Appl. Catal. B, 2016, 183, 269-281.

[32] L. Huang, X. Zhao, L. Zhang, L. Y. Shi, J. P. Zhang, D. S. Zhang, Nanoscale, 2015, 7, 2743-2749.

[33] C. K. Seo, B. Choi, H. Kim, C. H. Lee, C. B. Lee, Chem. Eng. J., 2012, 191, 331-340.

[34] P. Nakhostin Panahi, Environ. Prog. Sustain. Energy, 2017, 36, 1049-1055.

[35] J. H. Lee, Y. J. Kim, T. Ryu, P. S. Kim, H. Chang, S. Hong, Appl. Catal. B, 2017, 200, 428-438.

[36] P. R. Chen, R. Moos, U. Simon, J. Phys. Chem. C, 2016, 120, 25361-25370.

[37] Z. G. Li, Y. X. Chen, J. H. Li, X. N. Ren, S. X. Liu, J. D. Gao, J.W. Schwank, T. Zhang, W. K. Su, H. Z. Chang, RSC Adv., 2016, 104, 102570-102581.

[38] Y. H. Li, J. L. Deng, W. Y. Song, J. Liu, Z. Zhao, M. L. Gao, Y. Wei, L. Zhao, J. Phys. Chem. C, 2016, 120, 14669-14680.

[39] W. T. Mu, J. Zhu, S. Zhang, Y. Y. Guo, L. Q. Su, X. Y. Li, Z. Li, Catal. Sci. Technol., 2016, 6, 7532-7548.

[40] X. L. Tang, J. M. Hao, H. H. Yi, J. H. Li, Catal. Today, 2007, 126, 406-411.

[41] B. C. Huang, R. Huang, D. J. Jin, D. Q. Ye, Catal. Today, 2007, 126, 279-283.

[42] G. Marbán, R. Antuña, A. B. Fuertes, Appl. Catal. B, 2003, 41, 323-338.

[43] W. W. Yang, F. D. Liu, L. J. Xie, Z. H. Lian, H. He, Ind. Eng. Chem. Res., 2016, 10, 2677-2685.

[44] E. Tronconi, I. Nova, C. Ciardelli, D. Chatterjee, M. Weibel, J. Catal., 2007, 245, 1-10.

[45] Y. X. Deng, X. Chen, R. Shao, L. M. Hu, J. Tang, C. Q. Wang, Key Eng. Mat., 2016, 697, 275-278.

[46] G. Ramis, G. Busca, C. Cristiani, L. Lietti, P. Forzatti, F. Bregani, Langmuir, 1992, 8, 1744-1749.

[47] C. Cristiani, M. Bellotto, P. Forzatti, F. Bregani, J. Mater. Res., 1993, 8, 2019-2025.

[48] G. Busca, L. Lietti, G. Ramis, F. Berti, Appl. Catal. B, 1998, 18, 1-36.

[49] L. J. Alemany, L. Lietti, N. Ferlazzo, P. Forzatti, G. Busca, E. Giamello, F. Bregani., J. Catal., 1995, 26, 117-130.

[50] M. Kantcheva, V. Bushev, D. Klissurski, J. Catal., 1994, 145, 96-106.

[51] J. Marangozis, Ind. Eng. Chem. Res., 1992, 31, 987-994.

[52] G. Ramis, G. Busca, F. Bregani, P. Forzatti, Appl. Catal., 1990, 64, 259-278.

[53] M. Takagi-kawai, M. Soma, T. Onishi, K. Tamaru, Can. J. Chem., 2011, 58, 2132-2137.

[54] S. C. Xiong, X. Xiao, Y. Liao, H. Dang, W. P. Shan, S. J. Yang, Ind. Eng. Chem. Res., 2017, 54, 11011-11023.

[55] G. Tuenter, W. F. Van, Leeuwen, L. J. M. Snepvangers, Ind. Eng. Chem. Prod. Res. Dev., 2004, 25, 633-636.

[56] L. K. Boudali, A. Ghorbel, P. Grange, Appl. Catal. A, 2006, 305, 7-14.
[57] N. Y. Topsoe, J. A. Dumesic, H. Topsoe, J. Catal., 1995, 151, 241-252.

[58] L. Lietti, I. Nova, G. Ramis, L. Dall'Acqua, G. Busca, E. Giamello, P. Forzatti, F. Bregani, J. Catal., 1999, 187, 419-35.

[59] J. Yang, Q. Yang, J. Sun, Q. C. Liu, D. Zhao, W. Gao, L. Liu, Catal. Commun., 2015, 59, 78-82.

[60] N. Fernández-Miranda, M.A. Lopez-Anton, M. Díaz-Somoano, M.R. Martínez-Tarazona, Chem. Eng. J., 2016, 285, 77-82.

[61] H. Kamata, S. I. Ueno, T. Naito, A. Yukimura, Ind. Eng. Chem. Res., 2015, 47, 8136-8141.

[62] L. Tao, X. N. Zhang, C. T. Li, Y. Che, L. K. Zhao, Y. M. Zhou, Chin. J. Environ. Eng., 2015, 9, 2925-2932.

[63] H. Z. Tian, Y. Wang, K. Cheng, Y. P. Qu, J. M. Hao, Z. G. Xue, F. H. Chai, J. Air Waste Manage., 2012, 62, 576-586.

[64] S. Niksa, N. Fujiwara, J. Air Waste Manage., 2005, 55, 1866-1875.

[65] B. K. Zhang, J. Liu, G. L. Dai, M. Chang, C. G. Zheng, P. Combust. Inst., 2015, 35, 2855-2865.

[66] W. Gao, Q. C. Liu, C. Y. Wu, H. L. Li, Y. Li, J. Yang, G. F. Wu, Chem. Eng. J., 2013, 220, 53-60.

[67] H. Kamata, S. Ueno, N. Sato, T. Naito, Fuel Process. Technol., 2009, 90, 947-951.

[68] C. L. Senior, J. Air Waste Manage., 2006, 56, 23-31.

[69] Y. Eom, S. H. Jeon, T. A. Ngo, J. Kim, T. G. Lee, Catal. Lett., 2008, 121 219-225.

[70] H. Sheng, J. S. Zhou, Y. Q. Zhu, Z. Y. Luo, M. J. Ni, K. F. Cen, Energ. Fuel., 2009, 23, 253-259.

[71] A. S. Negreira, J. Wilcox, J. Phys. Chem. C, 2016, 117, 24397-24406.

[72] B. Zhao, X. W. Liu, Z. J. Zhou, H. Z. Shao, C. Wang, J. P. Si, M. H. Xu, Chem. Eng. J., 2014, 253, 508-517.

[73] D. Pudasainee, S. J. Lee, S. H. Lee, J. H. Kim, H. N. Jang, S. J. Cho, Y. C. Seo, Fuel, 2010, 89, 804-809.

[74] Y. Cao, Z. Y. Gao, J. S. Zhu, Q. H. Wang, Y. J. Huang, C. C. Chiu, B. Parker, P. Chu, W. P. Pant, Environ. Sci. Technol, 2008, 42, 256-261.

[75] Y. Cao, B. Chen, J. Wu, H. Cui, J. Smith, K. Chen, A. Paul Chu, W. P. Pan, Energy Fuels, 2016, 21, 145-156.

[76] C. U. I. Odenbrand, Chem. Eng. Res. Des., 2008, 86, 663-672.

[77] J. P. Chen, M. A. Buzanowski, R. T. Yang, J. E. Cichanowicz, J. Air Waste Manage, 1990, 40, 1403-1409.

[78] Q. H. Huang, L. Y. Song, H. He, W. G. Qiu, Y.C. Su, Chem. Res. Chinese $U ., 2016,32,414-417$.

[79] X. Y. Guo, [MS Dissertation], Brigham Young University, 2006, 25-28.

[80] L. Chmielarz, R. Dziembaj, T. Łojewski, A. Wẹgrzyn, T. Grzybek, J. Klinik, D. Olszewska, Solid State Ionics, 2001, 141-142, 715-719.

[81] C. Orsenigo, A. Beretta, P. Forzatti, J. Svachula, E. Tronconi, F. Bregani, A. Baldacci, Catal. Today, 1996, 27, 15-21.

[82] P. D. Ji, X. Gao, X. S. Du, C. H. Zheng, Z. Y. Luo, K. F. Cen, Catal. Sci. Technol., 2015, 6, 1187-1194.

[83] L. Wen, J. M. Chen, L. X. Yang, X. F. Wang, X. Caihong, X. Sui, L. Yao, Y. H. Zhu, J. M. Zhang, T. Zhu, W. X. Wang, Atmos. Environ., 2015, 101, 294-302.

[84] G. S. Qi, R. T. Yang, Appl. Catal. B, 2003, 44, 217-225.

[85] C. Orsenigo, L. Lietti, E. Tronconi, P. Forzatti, F. Bregani, Ind. Eng. Chem. Res., 1998, 37, 2350-2359.

[86] C. X. Liu, L. Chen, J. H. Li, L. Ma, H. Arandiyan, D. Yu, J. Y. Xu, J. M. Hao, Environ. Sci. Technol, 2012, 46, 6182-6189.

[87] L. Chen, J. H. Li, M. F. Ge, J. Phys. Chem. C, 2009, 113, 21177-21184.

[88] C. T. Campbell, C. H. F. Peden, Science, 2005, 309, 713-714.

[89] B. Murugan, A. V. Ramaswamy, J. Am. Chem. Soc., 2007, 129 3062-3063.

[90] W. Q. Xu, Y. B. Yu, C. B. Zhang, H. He, Catal. Commun., 2008, 9 , 1453-1457. 
[91] K. Cheng, T. Zhang, J. M. Li, Y. C. Wei, G. Y. Jiang, A. J. Duan, J. Liu, Z. Zhao, J. Environ. Sci., 2014, 26, 2106-2113.

[92] S. Youn, I. Song, D. H. Kim, J. Nanosci. Nanotechnol., 2016, 16, 4350-4356.

[93] K. J. Lee, P. A. Kumar, M. S. Maqbool, K. N. Rao, K. H. Song, H. P. Ha, Appl. Catal. B, 2013, 142-143, 705-717.

[94] Y. P. Zhang, W. Q. Guo, L. F. Wang, M. Song, L. J. Yang, K. Shen, H. T. Xu, C. C. Zhou, Chin. J. Catal., 2015, 36, 1701-1710.

[95] Y. P. Zhang, X. Q. Zhu, K. Shen, H. T. Xu, K. Q. Sun, C. C. Zhou, J. Colloid Interf. Sci., 2012, 376, 233-238.

[96] Q. Li, X. X. Hou, H. S. Yang, Z. X. Ma, J. W. Zheng, F. Liu, X. B. Zhang, Z. Y. Yuan, J. Mol. Catal. A, 2012, 356, 121-127.

[97] P. A. Kumar, Y. E. Jeong, S. Gautam, H. P. Ha, K .J. Lee, K. H. Chae, Chem. Eng. J., 2015, 275, 142-151.

[98] X. Zhao, L. Huang, S. Namuangruk, H. Hu, X. N. Hu, L. Y. Shi, D. S. Zhang, Catal. Sci. Technol., 2016, 6, 5543-5553.

[99] J. Q. Chao, H.He, L. Y. Song, Y. J. Fang, Q. M. Liang, G. Z. Zhang, W. G. Qiu, Z. Ran, Chem. J. Chin. Univ., 2015, 36, 523-530.

[100] R. H. Gao, D. S. Zhang, X. G. Liu, L. Y. Shi, P. Maitarad, H. R. Li, J. P. Zhang, W. G. Cao, Catal. Sci. Technol., 2013, 3, 191-199.

[101] L. M. Yu, Q. Zhong, S. L. Zhang, W. Zhao, R. Zhang, Comb. Sci. Technol., 2015, 187, 925-936.

[102] M. Q. Shen, C. X. Li, J. Q. Wang, L. L. Xu, W. L. Wang, J. Wang, RSC Adv., 2015, 5, 35155-35165.

[103] L. Schill, S. S. R. Putluru, A. D. Jensen, R. Fehrmann, Catal. Commun., 2014, 56, 110-114.

[104] Z. B. Wu, B. Q. Jiang, Y. Liu, W. K. Zhao, B. H. Guan, J. Hazard. Mater., 2007, 145, 488-494.

[105] D. Fang, F. He, D. Mei, Z. Zhang, J. L. Xie, H. Hu, Catal. Commun., 2014, 52, 45-48.

[106] H. H. Phil, M. P. Reddy, P. A. Kumar, L. K. Ju, J. S. Hyo, Appl. Catal. $B, 2008,78,301-308$.

[107] W. Zhao, Q. Zhong, T. J. Zhang, Y. X. Pan, RSC Adv., 2012, 2, 7906-7914.

[108] S. L. ZhaNG, Q. Zhong, Int. J. Environ. Sci. Dev., 2012, 3, 441-445.

[109] Q. Zhong, T. J. Zhang, Y. T. Li, W. H. Ma, H. X. Qu, Chem. Eng. J., 2011, 174, 390-395.

[110] S. L. Zhang, H. Y. Li, Q. Zhong, Appl. Catal. A, 2012, 435-436, 156-162.

[111] W. Zhao, Q. Zhong, RSC Adv., 2014, 4, 5653-5659.

[112] H. Y. Li, S. L. Zhang, Q. Zhong, J. Colloid Interf. Sci., 2013, 402, 190-195.

[113] W. Zhao, Q. Zhong, Y. X. Pan, R. Zhang, Chem. Eng. J., 2013, 228, 815-823.

[114] P. Forzatti, Appl. Catal. A, 2001, 222, 221-236.

[115] S. L. Zhang, X. N. Yang, Q. Zhong, J. Fluorine Chem., 2013, 153, 26-32.

[116] T. Tran, J. Yu, L. N. Gan, F. Guo, D. Phan, G. W. Xu, Catalysts, 2016, 6, 56/1-56/14.

[117] S. S. R. Putluru, L. Schill, A. Godiksen, R. Poreddy, S. Mossin, A. D. Jensen, R. Fehrmann, Appl. Catal. B, 2016, 183, 282-290.

[118] I. Nova, L. Dall Acqua, L. Lietti, E. Giamello, P. Forzatti, Appl. Catal. $B, 2001,35,31-42$.

[119] X. S. Liu, X. D. Wu, T. F. Xu, D. Weng, Z. C. Si, R. Ran, Chin. J. Catal., 2016, 37, 1340-1346.

[120] M. A .L. Vargas, M. Casanova, A. Trovarelli, G. Busca, Appl. Catal. $B, \mathbf{2 0 0 7}, 75,303-311$.

[121] M. Casanova, E. Rocchini, A. Trovarelli, K. Schermanz, I. Begsteiger, J. Alloys. Compd., 2006, 408-412, 1108-1112.

[122] M. Casanova, K. Schermanz, J. Llorca, A. Trovarelli, Catal. Today, 2012, 184, 227-236.

[123] A. Marberger, D. Ferri, M. Elsener, A. Sagar, C. Artner, K. Scher- manz, O. Kröcher, Appl. Catal. B, 2017, 218, 731-742.

[124] M. Casanova, J. Llorca, A. Sagar, K. Schermanz, A. Trovarelli, Catal. Today, 2015, 241, 159-168.

[125] A. J. Shi, X. Q. Wang, T. Yu, M. Q. Shen, Appl. Catal. B, 2011, 106, 359-369.

[126] J. W. Choung, I. S. Nam, S. W. Ham, Catal. Today, 2006, 111, 242-247.

[127] Y. K. Yu, X. R. Meng, J. S. Chen, J. X. Wang, Y. T. Chen, Water Air Soil Poll., 2015, 226, 1-10.

[128] Y. N. Hu, H. F. Cheng, Environ. Pollut., 2016, 218, 1209-1221.

[129] G. R. Golding, C. A. Kelly, R. Sparling, P. C. Loewen, T. Barkay, Environ. Sci. Technol., 2007, 41, 5685-5692.

[130] Us Epa 000 A, Mercury and Air Toxics Standards (MATS) for Power Plants, 2013.

[131] E. G. Pacyna, J. M. Pacyna, K. Sundseth, J. Munthe, K. Kindbom, S. Wilson, F. Steenhuisen, P. Maxson, Atmos. Environ., 2010, 44, 2487-2499.

[132] Y. W. Tan, R. Mortazavi, B. Dureau, M. A. Douglas, Fuel, 2004, 83, 2229-2236.

[133] B. A. Dranga, L. Lazar, H. Koeser, Catalysts, 2012, 2, 139-170.

[134] B. A. Dranga, H. Koeser, Appl. Catal. B, 2015, 166-167, 302-312.

[135] W. Q. Xu, H. R. Wang, X. Zhou, T. Y. Zhu, Chem. Eng. J., 2014, 243, 380-385.

[136] H. L. Li, X .G. Wang, C. Y. Wu, L. Q. Li, Y. C. Zhao, J. Y. Zhang, J. Eng. Thermophys, 2013, 34, 1775-1778.

[137] L. K. Zhao, C. T. Li, X. N. Zhang, G. M. Zeng, J. Zhang, Y. E. Xie, Environ. Sci. Pollut. Res., 2016, 23, 1471-1481.

[138] H. L. Li, C. Y. Wu, Y. Li, J. Y. Zhang, Appl. Catal. B, 2012, 111-112, 381-388.

[139] H. L. Li, S. K. Wu, C. Y. Wu, J. Wang, L. Q. Li, K. M. Shih, Environ. Sci. Technol., 2015, 49, 7373-7379.

[140] H. L. Li, L. Zhu, S. K. Wu, Y. Liu, K. Shih, Int. J. Coal Geol., 2017, 170, 69-76.

[141] L. K. Zhao, C. T. Li, S. H. Li, Y. Wang, J. Y. Zhang, T. Wang, G. M. Zeng, Appl. Catal. B, 2016, 198, 420-430.

[142] Z. J. Zhou, X. W. Liu, Z. Q. Liao, H. Z. Shao, C. Lv, Y. C. Hu, M. H. Xu, Fuel Process. Technol., 2016, 152, 285-293.

[143] X. P. Zhang, Y. Z. Cui, B. J. Tan, J. X. Wang, Z. F. Li, G. H. He, RSC Adv., 2016, 6, 88332-88339.

[144] Z. S. Wei, Y. W. Luo, B. R. Li, Z. Y. Chen, Q. H. Ye, Q. R. Huang, J. C. He, J. Ind. Eng. Chem., 2015, 24, 315-321.

[145] Z. Y. Liu, X. Li, J. Y. Lee, T.B. Bolin, Chem. Eng. J., 2015, 275, 1-7.

[146] H. H. Li, J. J. Hu, W. He, Can. J. Chem. Eng., 2016, 94, 1486-1494.

[147] S. C. Xiong, X. Xiao, N. Huang, H. Dang, Y. Liao, S. J. Zou, S. J. Yang, Environ. Sci. Technol., 2017, 51, 531-539.

[148] J. P. Yang, Y. C. Zhao, L. Chang, J. Y.Zhang, C. G. Zheng, Environ. Sci. Technol., 2015, 49, 8210-8218.

[149] W. J. Huang, H. M. Xu, Z. Qu, S. J. Zhao, W. M. Chen, N. Q. Yan, Fuel Process. Technol., 2016, 149, 23-28.

[150] C. M. Chen, W. B. Jia, S. T. Liu, Y. Cao, Appl. Surf. Sci., 2018, 436, 1022-1029.

[151] S. J. Zhao, Z. Qu, N. Q. Yan, Z. Li, H. M. Xu, J. Mei, F.Q. Quan, Catal. Sci. Technol., 2015, 5, 2985-2993.

[152] N. Q. Yan, W. M. Chen, J. Chen, Z. Qu, Y. F. Guo, S. J. Yang, J. P. Jia, Environ. Sci. Technol., 2011, 45, 5725-5730.

[153] W. M. Chen, Y. P. Ma, N. Q. Yan, Z. Qu, S. J. Yang, J. K. Xie, Y. F. Guo, L. G. Hu, J. P. Jia, Fuel, 2014, 133, 263-269.

[154] L. K. Zhao, C. T. Li, Y. Wang, H. Y. Wu, L. Gao, J. Zhang, G. M. Zeng, Catal. Sci. Technol., 2016, 6, 6076-6086.

[155] L. K. Zhao, C. T. Li, J. Zhang, X. N. Zhang, F. M. Zhan, J. F. Ma, Y. E. Xie, G. M. Zeng, Fuel, 2015, 153, 361-369.

[156] X. N. Zhang, C. T. Li, L. K. Zhao, J. Zhang, G. M. Zeng, Y.E. Xie, M. E. 
Yu, Appl. Surf. Sci., 2015, 347, 392-400.

[157] M. Z. Zhang, P. Wang, Y. Dong, H. Sui, D. D. Xiao, Chem. Eng. J., 2014, 253, 243-250.

[158] C. M. Chen, W. B. Jia, S. T. Liu, Y. Cao, B. Zhao, J. Q. Wang, Korean J. Chem. Eng., 2018, 35, 637-644.

[159] Y. Li, P. D. Murphy, C. Y. Wu, K. W. Powers, J. C. J. Bonzongo, Environ. Sci. Technol., 2008, 42, 5304-5309.

[160] G. L. Chi, B. X. Shen, R. R. Yu, C. He, X. Zhang, J. Hazard. Mater, 2017, 330, 83-92.

[161] H. Over, J. Phys. Chem. C, 2017, 116, 6779-6792.

[162] D. Teschner, G. Novell-Leruth, R. Farra, A. Knop-Gericke, R. Schlögl, L. Szentmiklósi, M. G. Hevia, H. Soerijanto, R. Schomäcker, J. Pérez-Ramírez, N. López., Nat. Chem., 2012, 4, 739-745.

[163] M. H. Kim, S. W. Ham, J. B. Lee, Appl. Catal. B, 2010, 99, 272-278.

[164] M. Colombo, I. Nova, E. Tronconi, Chem. Eng. Sci., 2012, 75, 75-83.

[165] A. Scheuer, W. Hauptmann, A. Drochner, J. Gieshoff, H. Vogel, M. Votsmeier, Appl. Catal. B, 2012, 111-112, 445-455.

[166] T. E. Bell, L. Torrente-Murciano, Top. Catal., 2016, 59, 1438-1457.

[167] T. Schwämmle, F. Bertsche, A. Hartung, J. Brandenstein, B. Heidel, G. Scheffknecht, Chem. Eng. J., 2013, 222, 274-281.

[168] F. Li , C. Z. Yu, P. Zhang, Elec. Power Technol. Environ. Prot., 2010, $26,18-21$.

[169] Y. F. Hu, Y.F. Bai, Energ. Conserv. Technol, 2007, 142, 152-156.

[170] P. Forzatti, I. Nova, A. Beretta, Catal. Today, 2000, 56, 431-441.

[171] J. P. Dunn, H. G. Stenger, I. E. Wachs, J. Catal., 1999, 181, 233-243.

[172] S. Morikawa, H. Yoshida, K. Takahashi, S. Kurita, Chem. Lett., 1981, 251-254.

[173] M. Kobayashi, R. Kuma, A. Morita, Catal. Lett., 2006, 112, 37-44.

[174] M. Kobayashi, R. Kuma, S. Masaki, N. Sugishima, Appl. Catal. B, 2005, 60, 173-179.

[175] T. Zhou, S. G. Liu, M. Z. Tang, C. W. Chen, Y. S. Xu, J. M. Wu, J. Chin. Ceram. Soc., 2012, 37, 317-324.

[176] Z. Fan, H. He, J. Li, W. Linyan, L. Y. Wu, Z. P. Deng, Ind. Catal, 2012, 20, 71-76.

[177] D. Ye, R. Y. Qu, H. Song, C. H. Zheng, X. Gao, Z. Y. Luo, M. J. Ni, K. F.
Cen, RSC Adv., 2016, 6, 55584-55592.

[178] W. W. Shi, [MS Dissertation], South China University of Technology, 2013, 22-36.

[179] Q. B. Xia, W. W. Shi, Z. Zhong, F. Wu, H. F. Fang, J. Zhao, L. Liao, L. Q. Ma, CN Patent 103920503 A, 2014.

[180] J. H. Li, Y. Peng, K. Z. Li, J. M. Hao, CN Patent 2014/092858, 2015.

[181] S. T. Choo, S. D. Yim, I. S. Nam, S. W. Ham, J. B. Lee, Appl. Catal. B, 2003, 44, 237-252.

[182] M. Kobayashi, M. Hagi, Appl. Catal. B, 2006, 63, 104-113.

[183] R. Huang, L. Zhou, L. Chen, H. H. Liu, D. Cheng, W. C. Xi, P. Yuan, Q. L. Deng,W. Liu, M. H. Duan, Y. Hong, X. Z. Huang, L. S. Wei, S. F. Long, P. X. Yang, CN Patent 201310192488.8, 2013.

[184] Y. J. Zheng, A. D. Jensen, J. E. Johnsson, Ind. Eng. Chem. Res., 2004, 43, 941-947.

[185] Y. Peng, J. H. Li, W. B. Shi, J. Y. Xu, J. M. Hao, Environ. Sci. Technol, 2012, 46, 12623-12629.

[186] Y. K. Yu, J. X. Wang, J. S. Chen, X. R. Meng, Y. J. Chen, H. Chi, Ind. Eng. Chem. Res., 2014, 53, 16229-16234.

[187] Y. Peng, J. H. Li, L. Chen, J. H. Chen, J. Han, H. Zhang, W. Han, Environ. Sci. Technol., 2012, 46, 2864-2869.

[188] F. S. Tang, B. L. Xu, H. H. Shi, J. H. Qiu, Y. N. Fan, Appl. Catal. B, 2010, 94, 71-76.

[189] X. S. Du, X. Gao, Y. C. Fu, F. Gao, Z. Y. Luo, K. F. Cen, J. Colloid. Interf. Sci., 2012, 368, 406-412.

[190] Z. Liu, Y. Li, T. L. Zhu, H. Su, J. Z. Zhu, Ind. Eng. Chem. Res., 2014, 53, 12964-12970.

[191] Y. X. Pan, W. Zhao, Q. Zhong, W. Cai, H. R. Li, J. Environ. Sci., 2013, 25, 1703-1711.

[192] M. Aguilar-Romero, R. Camposeco, S. Castillo, J. Marín, V. Rodríguez-González, L. A. García-Serrano, I. Mejía-Centeno, Fuel, 2017, 198,123-133.

[193] M. H. Kim, S. W. Park, Catal. Commun., 2016, 86, 82-85.

[194] S. J. Yang, C. Z. Wang, L. Ma, Y. Peng, Z. Qu, N. Q. Yan, J. H. Chen, H. Z. Chang, J. H. Li, Catal. Sci. Technol, 2013, 3, 161-168.

[195] X. Zhao, L. Huang, H. R. Li, H. Hu, J. Han, L.Y. Shi, D. S. Zhang, Chin. J. Catal., 2015, 36, 1886-1899.

[196] T. F. Xu, X. D. Wu, X. S. Liu, L. Cao, D. Weng, Q. W. Lin, J. Environ. Sci., 2017, 57, 110-117.

\title{
改性钒钛基 SCR 催化剂的研究进展
}

\author{
陈传敏 ${ }^{*}$, 曹 悦, 刘松涛, 陈建猛, 贾文波 \\ 华北电力大学 (保定) 环境科学与工程系, 河北保定 071003
}

\begin{abstract}
摘要: 钒钛基选择性催化还原催化剂是目前燃煤电厂应用最为广泛的脱硝催化剂. 由于传统钒钣基催化剂存在低温脱硝 效率低、热稳定性差、单质录氧化效率低、二氧化硫氧化、氨逃逸、碱金属中毒等问题, 人们开始尝试通过对传统 SCR 催化 剂进行改性, 以期改善其综合性能. 本文从 (1) 拓宽催化剂的反应温度窗口, 尤其是向低温区扩展, (2) 提高催化剂的热稳定 性, (3) 协同氧化单质永, (4) 控制氨逃逸, (5) 降低 $\mathrm{SO}_{2}$ 至 $\mathrm{SO}_{3}$ 的转化率和 (6) 提高催化剂抗碱金属中毒性能等方面综述了 改性钒钛基 SCR 催化剂的研究进展, 总结了其催化性能和相关影响机理.

研究表明, 某些金属及非金属的改性可以增加钒钛基 SCR 催化剂的表面酸度、活性位点及氧化还原性能, 非金属的掺 杂还可以抑制 $\mathrm{TiO}_{2}$ 载体由锐钛矿向金红石型转化、增加表面氧空位, 从而改善了钒钛基催化剂的低温脱硝性能; 硅、铇、钡 和稀土金属等的添加也可抑制 $\mathrm{TiO}_{2}$ 的金红石化过程, 铅、钾则改变了钥氧化物的存在形态, 抑制其高温聚合, 提高了钒钛 基催化剂的热稳定性; 贵金属、过渡金属、金属氯化物及非金属的改性改变了钒钛基催化剂的录氧化机制, 均可有效促进 低氯甚至无氯条件下钒钛基催化剂对单质录的氧化; 贵金属钉及助剂钿添加的钒钛基催化剂可在维持较高脱硝效率的同 时, 实现单质录及逃逸氨的高效去除, 在 SCR 尾部将逃逸氨选择性氧化生成无害的氮气和水; 被铜、氧化钡、氧化硅等物质 改性后, 更多的钒以低价态存在, 使催化剂的氧化还原性能降低, 并抑制了二氧化硫的吸附, 从而减少了三氧化硫的生成; 由于具有高储氧能力和氧化还原特性, 还可降低碱金属的吸附量, 铈的掺杂可提高钒钛基催化剂的抗碱金属中毒性能.
\end{abstract}


此外, 本文还汇总了包括贵金属 (如银、钉)、过渡金属 (如锰、铁、铜、铅等)、稀土金属 (铈、镨) 等金属、金属氯化物 (如氯 化铜、氯化钙) 及非金属 (氟、硫、硅等) 改性钒钛基 SCR 催化剂的优缺点. 基于前人研究及作者观点, 改性组分的掺杂有利 于进一步提高钒钛基催化剂的综合性能, 具有巨大的发展潜力, 也是在现有基础上实现多污染物控制的方法之一. 关键词：钒钛基催化剂; 选择性催化还原; 低温脱硝; 录氧化; 逃逸氨; 二氧化硫氧化

收稿日期: 2018-03-05. 接受日期: 2018-04-03. 出版日期: 2018-08-05.

*通讯联系人. 电话: (0312)7525510; 电子信箱：hdccm@126.com

基金来源：河北省科学技术计划项目 (16273703D); 中央高校基本科研业务费专项资金 (2015ZD24, 2017XS123).

本文的电子版全文由Elsevier出版社在ScienceDirect上出版(http://www.sciencedirect.com/science/journal/18722067). 